\title{
Against "Overwhelming" Appellate Activism: Constraining Harmless Error Review
}

\author{
Gregory Mitchell $\dagger$
}

Today, most constitutional errors at trial are subject to harmless error review. In deciding whether an error was harmless, appellate courts apply one of the three harmless error tests endorsed by the Supreme Court. The first test focuses on the error's likely impact on the verdict. The second test focuses on whether the properly admitted evidence of guilt is so overwhelming that the verdict should stand regardless of the error's impact. The third test is a hybrid of the first two, balancing the impact of the error against the weight of the untainted evidence. The author of this Comment argues that, given the differences in application and result associated with each of these tests, an appellate court's choice of test may be dispositive of whether a conviction is upheld or overturned. This disparity is indefensible and necessitates the adoption of a uniform test of harm. This Comment examines the three tests to determine which should be chosen. The author concludes that the overwhelming evidence test has no place in harmless error review. Such an approach is based on the faulty assumption that an appellate court may reliably assess guilt. Moreover, allowing the appellate court to assess guilt intrudes impermissibly on the role of the jury as conscience of the community. The author argues that the proper test of harm is the impact-on-the-verdict test because it limits the appellate court to reviewing the procedural fairness of a trial rather than the factual accuracy of a trial.

\section{INTRODUCTION}

In the 1967 case of Chapman v. California, ${ }^{1}$ the Supreme Court held that violation of a criminal defendant's constitutional rights at trial does not necessarily entitle the defendant to a new trial. ${ }^{2}$ Instead, certain constitutional errors are acceptable if they are harmless in their effect at trial. In establishing this rule, the Court hoped to

block setting aside convictions for small errors or defects that have

Copyright @ 1994 California Law Review, Inc.

$\dagger$ B.A. 1988, University of Arkansas; M.A. 1990, University of California, Berkeley; J.D. 1993, Boalt Hall School of Law, University of California, Berkeley; Ph.D. 1994, University of California, Berkeley.

1. 386 U.S. 18 (1967).

2. Id. at 22 . 
little, if any, likelihood of having changed the result of the trial. ... [T] here may be some constitutional errors which in the setting of a particular case are so unimportant and insignificant that they may, consistent with the Federal Constitution, be deemed harmless, not requiring the automatic reversal of the conviction. ${ }^{3}$

Thus, even constitutional rights may at times be rights without remedies. ${ }^{4}$

This constitutional harmless error doctrine ${ }^{5}$ has been plagued by two central ambiguities since its inception: (1) uncertainty about the range of constitutional errors subject to harmless error review, ${ }^{6}$ and (2) within the class of errors subject to such review, uncertainty about how harmless error should be judged. ? That is, what types of constitutional errors may be

3. Id.

4. As Professor Meltzer points out, constitutional rights are potentially always rights without remedies because the Constitution arguably does not guarantee criminal defendants a right to appeal. See Daniel J. Meltzer, Harmless Error and Constitutional Remedies, 61 U. Crr. L. Rev. 1, 2 (1994). As of now, however, all states do provide for appeals of serious criminal convictions. Id. at 2-3, 6 . Additionally, in 1891, Congress enacted a statute granting all federal criminal defendants a right of appeal. See id. at $6 \&$ n.29 (citing Act of March 3, 1891, ch. 517 \& 5, 26 Stat. 826). In any event, federal law preempts state law on questions of federal constitutional error. Chapman, 386 U.S. at 21; Meltzer, supra at 1.

5. The holding of Chapman applies specifically to federal constitutional violations in federal or state courts. Chapman, 386 U.S. at 21 . Violations implicating statutorily created but nonconstitutional rights are subject to review for harmlessness under Rule 52 of the Federal Rules of Criminal Procedure or under similar state rules. See Fed. R. CRIM. P. 52(a); United States v. Lane, 474 U.S. 438, 445, 460 (1986). Also, the holding of Chapman now applies only to the direct review of constitutional errors. Prior to Brecht v. Abrahamson, 113 S. Ct. 1710 (1993), courts assessed the harm of constitutional errors under the Chapman rule whether considered on direct review or on habeas corpus review. In Brecht, however, the Court held that Chapman applies only to direct review of constitutional errors and that the "substantial and injurious effect" standard of Kotteakos v. United States, 328 U.S. 750, 776 (1946), once applied only to nonconstitutional errors, should be applied to review of constitutional errors in habeas cases. Brecht, $113 \mathrm{~S}$. Ct. at 1721-22. This Comment considers only the direct review of federal constitutional violations. However, some habeas cases decided before Brecht are included in the discussion.

For a discussion of the relationship between Chapman and Brecht, see John H. Blume \& Stcven P. Garvey, Harmless Error in Federal Habeas Corpus After Brecht v. Abrahamson, 35 WM. \& MARY L. Rev. 163 (1993). For a comparison of harmless enror rules applicable to nonconstitutional versus constitutional violations, see Lane, 474 U.S. at 460-62 (Brennan, J., concurring in part and dissenting in part) (stating that the primary distinction is that tests of nonconstitutional error are generally less strict); Stephen A. Saltzburg, The Harm of Harmless Error, 59 VA. L. Rev. 988, 999-1012 (1973) (discussing why different standards have been applied to the two kinds of error); Erika Plumlee, Comment, "To Err Is Human"-But Is It Harmless?: Texas Rules of Appellate Procedure Rule 81(b)(2) and the Court of Criminal Appeals' Effort to Fashion a Workable Standard of Review, 21 TEX. TECH L. REv. 2205, 2206-11 (1990) (tracing the evolution of harmless error rules).

6. See, e.g., The Supreme Court, 1985 Term-Leading Cases, 100 Harv. L. Rev. 100, 107 (1986) ("The Supreme Court has yet to develop a coherent standard for determining when a violation of the federal Constitution ... may constitute 'hamless crror.' "); Robert Pondolf, Comment, Principles for Application of the Harmless Error Standard, 41 U. CHI. L. REv. 616, 616 (1974) ("The Court has failed ... to announce a coherent rationale as to which violations are to be reviewed by the strict 'automatic reversal' standard and which by the more lenient 'harmless error' standard.").

7. See, e.g., Commonwealth v. Perez, 581 N.E.2d 1010, 1017 (Mass. 1991) ("The United States Supreme Court has used different formulations of [the harmless error] test."); Charles F. Campbell, $\boldsymbol{J}_{\boldsymbol{r}}$., An Economic View of Developments in the Harmless Error and Exclusionary Rules, 42 BAYLoR L. REv. $499,521-24$ (1990) (noting vacillation by the Court between various standards for determining the harm 
harmless, and how is this harmlessness to be determined?

The Supreme Court recently addressed the first ambiguity in Arizona v. Fulminante ${ }^{8}$ and held that an error may be reviewed for harmlessness if it occurs during the presentation of evidence at trial. ${ }^{9}$ An error demands automatic reversal, however, if it alters the basic structure of a trial. ${ }^{10}$ Thus, for example, the use of a coerced confession in the prosecution's case-in-chief, as in Fulminante, is reviewable, ${ }^{11}$ whereas the lack of an impartial judge is not. ${ }^{12}$ Although the Fulminante decision will not entirely settle debate on this first issue, ${ }^{13}$ it does provide some guidance to lower courts: if an error altered the basic structure of a trial such that a rehable verdict could not have been attained, the error automatically requires reversal and a new trial is in order; otherwise, the error may be reviewed for harmlessness. ${ }^{14}$

The Court has been inuch less forthright in dealing with the second ambiguity. Indeed, rather than clarify the test of harmless error, the Court

caused by an error); Daniel J. Komstein, A Bayesian Model of Harmless Error, 5 J. LEGAL STUd. 121, 122 (1976) ("Over the years, courts have used varying verbal formulae to determine whether an error is harmless.").

8. 499 U.S. 279 (1991).

9. Id. at 307-08.

10. Id. at 309-10. The result reached by the Court mirrors Professor Campbell's analysis of reviewable versus unreviewable errors:

Apparently, in every circumstance where violations have warranted reversal, it is quite difficult to know whether the evidence may have affected the outcome, or whether the likelihood that the evidence has infiuenced the outcome is so strong that it is not worth expending the judicial resources necessary to evaluate the effect of the error in particular cases.

Campbell, supra note 7, at 519.

11. Fulminante, 499 U.S. at 310 . The Court reasoned that " $[t]$ he admission of an involuntary confession is a 'trial error,' similar in both degree and kind to the erroneous admission of other types of evidence." Id.

12. See Tumey v. Ohio, 273 U.S. 510 (1927) (holding that the right to an impartial judge is fundamental).

13. See, e.g., Charles J. Ogletree, Jr., Arizona v. Fulminante: The Harm of Applying Harmless Error to Coerced Confessions, 105 HARV. L. REv. 152, 161-72 (1991) (criticizing the Fulminante decision for failing to distinguish persuasively between errors reviewable under harmless error analysis and those that require automatic reversal); Toun Stacy, The Search for the Truth in Constitutional Criminal Procedure, 91 Colum. L. REv. 1369, 1381-83 (1991) (arguing that the Fulminante decision belittles certain constitutional rights); Craig Goldblatt, Comment, Harmless Error as Constitutional Common Law: Congress's Power to Reverse Arizona v. Fulminante, 60 U. CHI. L. REv. 985, 985 (1993) (detailing the controversy surrounding Fulminante); Kenneth R. Kenkel, Note, Arizona v. Fulminante: Where's the Harm in Harmless Error?, 81 Ky, L.J. 257, 257 \& nn.3-4 (1992-93) (same); cf. Douglas Nichols, Sullivan v. Louisiana: Automatic Reversal for Erroneous Reasonable-Doubt Jury Instructions, 68 Tul. L. REv. 1017, 1022-23 (1994) (noting that in Sullivan v. Louisiana, 113 S. Ct. 2078 (1993), the Court acknowledged the Fulminante test but largely relied on a different test for determining whether an error could be reviewed for harmlessness).

14. Although the Fulminante dissenters characterized the trial error/structural error distinction as a "meaningless dichotomy," 499 U.S. at 290 , the inajority's opinion is meaningful because it explicitly lists errors that should be considered "structural" and thus never harmless, id. at 309-10. Specifically, the Court lists deprivation of right to counsel, lack of impartial judge, discrimination in jury selection, denial of right to self-representation, and denial of right to public trial as unreviewable structural errors. Id. 
has offered at least three different approaches to judging an error's harm. ${ }^{15}$ As a result, courts today apply disparate tests of harmless error. ${ }^{16}$ This disparity is significant because the different tests, when applied to the same set of facts, may yield different results. A court's choice of harmless error test alone, and not the merits of a case, may determine the outcome of appellate review. ${ }^{17}$ Accordingly, the situation is ripe for the Court to address directly the proper definition of harmless error. ${ }^{18}$

The lack of a uniform definition of harmless error takes on increasing importance as more and more errors become subject to harmless error review. ${ }^{19}$ Today, errors to which harmless error analysis does not apply "are the exception and not the rule." 20 In fact, a presumption in favor of harmless error review exists. ${ }^{21}$ A criminal defendant seeking a new trial for constitutional error below should no longer count on the error falling into the category of automatic reversal. Rather, a defendant must now rely on the government's inability to prove the error harmless. ${ }^{22}$ Since the particu-

15. See infra Section I.A.

16. See infra notes 77-79 and accompanying text.

17. Kordenbrock v. Scroggy, 919 F.2d 1091 (6th Cir. 1990) (en banc), cert. denied, 499 U.S. 970 (1991), serves as a good illustration of this effect. In this case heard by thirteen Sixth Circuit judges, seven of the judges chose one of the tests espoused by the Supreme Court, applied it to the facts, and reached one conclusion; the remaining six judges chose a competing test also espoused by the Court, applied it to the facts, and reached a directly contrary conclusion. For further discussion of Kordenbrock, see infra text accompanying notes 95-98.

18. Supreme Court Rule 10(1) provides nonbinding guidelines as to when certiorari should be granted. The current state of harmless error law falls into one category for granting certiorari, namely, where there is conflict across circuits and/or state supreme courts on a significant point of law. See Sup. CT. R. 10(1)(a), (b); see also Tom Staunton, Note, How to Decide: Case Selection and Judicial Review, 1992/1993 ANN. SuRv. AM. L. 347, 351-52 (discussing Rule 10 and the reasons why certiorari is granted).

19. See United States v. Innamorati, 996 F.2d 456, 475 n.5 (1st Cir. 1993) ("Errors that the Supreme Court deems to warrant automatic reversal are rare."); Toun Stacy \& Kim Dayton, Rethinking Harmless Constitutional Error, 88 CoLum. L. REv. 79, 80 (1988) (arguing that harmless error rule has been gradually applied "to more and more types of constitutional errors"). A 1979 study provided evidence that the absolute and relative number of cases involving possible harmless error have grown significantly since the Chapman decision. See Donald A. Winslow, Note, Harmful Use of Harmless Error in Criminal Cases, 64 CoRNezr L. Rev. 538, 544-48 (1979) (providing data from federal circuit cases on mcreased use of harmless error analysis); see also Steven H. Goldberg, Harmless Error: Constitutional Sneak Thief, 71 J. CRIM. L. \& CRIMINOLOaY 421, 421 n.3 (1980) (supplementing the data discussed in Winslow, supra, and estimating the high frequency with which the doctrine is applied).

20. Rose v. Clark, 478 U.S. 570, 578 (1986).

21. Id. at 579 ("[I]f the defendant had counsel and was tried by an impartial adjudicator, there is a strong presunption that any other errors that may have occurred are subject to harmless-error analysis."); see also Sullivan v. Louisiana, 113 S. Ct. 2078, 2083 (1993) (Rehnquist, C.J., coneurring) ("[ $] \mathrm{t}$ is the rare case in which a constitutional violation will not be subject to harmless-error analysis.").

22. One consistency within harmless error doctrine has been the placement of the burden of proving harmlessness on the state. See, e.g., Satterwhite v. Texas, 486 U.S. 249, 256 (1988) ("We generally have held that if the prosecution can prove beyond a reasonable doubt that a constitutional error did not contribute to the verdict, the error is harmless and the verdict may stand."); Chapman v. California, 386 U.S. 18, 24 (1967) ("Certainly error, constitutional error, in illegally admitting highly prejudicial evidence or comments, casts on someone other than the person prcjudiced by it a burden to show that it was harmless."). But see Goldberg, supra note 19, at 428 \& n.77 (arguing that Rehnquist's majority opinion in Schneble v. Forida, 405 U.S. 427, 432 (1972), left unclear who was to carry the 
lar test of harm applied bears directly on how difficult a task the government faces in meeting its burden, determining the proper definition of harm has become the single most important issue of law in harmless error cases. ${ }^{23}$

Courts evaluate harmless error under one of two distinct tests or a hybrid of the two. Under the first test, an error is not harmless if it is likely to have had even a minimal mipact on juror deliberations. Under the second test, an error is harmless if overwhelming, untainted evidence of guilt exists in the trial record. ${ }^{24}$ Thus, under this second test, if it appears to the appellate court from the record that, notwithstanding the error, the defendant is clearly guilty, the error is harmless. Under the hybrid approach, the court balances the impact of the error against the overwhelmingness of the untainted evidence. The outcome will rely on either the severity of the error or the weight of the untainted evidence, depending upon what the court chooses to emphasize. ${ }^{25}$

The validity of the second, "overwhelming evidence of guilt" test and its hybrid variant has been implicated by the Supreme Court's recent opinion in Sullivan v. Louisiana. ${ }^{26}$ Although it did not explicitly address the

burden of proof); see also Blume \& Garvey, supra note 5, at 166-69 (noting that Chief Justice Rehnquist, in Brecht v. Abrahamson, 113 S. Ct. 1710 (1993), argued that the burden should be on defendants in habeas cases, whereas Justice Stevens, in his dissent, argued that the burden should be on the prosecution).

23. Professor Goldberg argues that the primary legal issue is whether constitutional errors should ever be deemed harmless. See Goldberg, supra note 19, at 441 ("As to constitutional rights there should be no harmless error."). The continued existence of the harmless error doctrine is, however, guaranteed for the foreseeable future. Since Chapman, the Court has not once considered the validity of the doctrine. Moreover, rather than curtail operation of the doctrine, the Court has only expanded its domain. Professor Goldberg himself acknowledges appellate courts' frequent use of the doctrine. See id. at 421 n.3.

Professor Meltzer, in contrast, argues that harmless error review is not constitutionally mandated because there is no constitutional guarantee of criminal appeal in the first place. See Meltzer, supra note 4, at 2-3,5. Professor Meltzer does not suggest, however, that harmless error review should be eliminated, but rather that state appellate courts may arguably be allowed to erect loose standards of harm (i.e., standards which allow easy affirmance of convictions) if they so desire:

[S]uppose a state conferred on its appellate courts jurisdiction to reverse a criminal conviction only if the error probably affeeted the outcome-a standard far less protective of defendants than that of Chapman. Why would affirmance of a conviction under that standard raise a federal question if the state might have provided no appeal whatsoever?

Id. at 3 (footnote omitted). A similar response as that above applies here: there is evcry indication that the Court will continue use of the doctrine and that it will not allow courts to impose whatever tests of harm they desire. See infra text accompanying notes 174-77 (discussing the Court's recent decision in Sullivan v. Louisiana, 113 S. Ct. 2078 (1993)).

24.

In Chapman, the Court stated the proper inquiry to be "whether there is a reasonable possibility that the evidence complained of might have contributed to the conviction." In other eases involving constitutional error, the Court phrased the standard in tcrms of whether overwhelming evidence of the defendant's guilt exists without the erroneously admitted evidence.

Commonwealth v. Perez, 581 N.E.2d 1010, 1017 (Mass. 1991) (citation omitted) (quoting Chapman, 386 U.S. at 24).

25. See Delaware v. Van Arsdall, 475 U.S. 673, 684 (1986) (listing five factors to be considered by a court in deciding whether an error is harmless). For a full description of the tests, see infra Part $I$.

26. 113 S. Ct. 2078 (1993). 
question of how harmless error should be judged, ${ }^{27}$ the Court endorsed a theory of appellate restraint that has dire implications for the overwhelming-evidence test. When Justice Scalia wrote that the proper role for the appellate court in a harmless error case is not "to hypothesize a guilty verdict" but rather to determine "whether the guilty verdict actually rendered in this trial was surely unattributable to the error," ${ }^{28}$ he indirectly called into question the use of the overwhelming-evidence approach to harmless error.

The Court has on occasion refused to engage in harmless error review because it would require "unguided speculation" by the reviewing court. ${ }^{29}$ Before Sullivan, however, this concern had never been voiced so strongly by a majority of the Court. Nor has the linkage between the proper role of the appellate court and the proper definition of harm ever been made so clear. Following Sullivan, any harmless error test that permits an appellate court to engage in unguided speculation about guilt-that, in effect, allows the appellate court to sit as a new jury - should be considered an impermissible test.

As will be shown, the overwhelming-evidence test permits just what Sullivan sought to avoid. Under this test, appellate review substantially intrudes on the province of the trial court because it allows the appellate court reviewing the trial record to come to its own, independent conclusion of guilt. ${ }^{30}$ Thus the court does not ask what effect an error had "upon the guilty verdict in the case at hand." 31 If a defendant is guilty by the appellate court's judgment, as shown by overwhelming-evidence, what a jury might have done at an error-free trial is irrelevant.

This degree of appellate-level factfinding is undesirable for two reasons. First, it places the appellate court in the position of trier of fact, a role traditionally reserved for the jury. This undermines the jury's function as the conscience of the community and intrudes on the Sixth Amendment right to trial by jury. Second, it allows appellate judges, who are poorly situated to make any factual determination, to decide the ultimate fact: whether the defendant is guilty or not guilty.

Of course, appellate review always involves some second-guessing of the imitial factfinder's conclusions. ${ }^{32}$ The question is what degree of second-guessing is appropriate in harmless error cases. Unless one believes

27. Sullivan discussed the appropriate test of harm in the context of deciding whether a particular constitutional error should be subject to harmless error review. Id. at 2082-83.

28. Id. at 2081-82.

29. See, e.g., Holloway v. Arkansas, 435 U.S. 475, 491 (1978).

30. See Brodniak v. State, 779 P.2d 71, 76 (Mont. 1989) (Hunt, J., dissenting) ("The overwhelming evidence test used in this opinion places the majority in the uncomfortable position of factfinder, forcing the majority to reweigh and, to some extent, mischaracterize the evidence.").

31. Sullivan, $113 \mathrm{~S}$. Ct. at 2081 .

32. See id. at 2084 (Rehnquist, C.J., concurring) ("[A]ny time an appellate court conducts harmless-error review it necessarily engages in some speculation as to the jury's decisionmaking process; for in the end no judge can know for certain what factors led to the jury's verdict."). 
laws can exert little or no influence on judges' decisions, ${ }^{33}$ it is worthwhile to consider the degree to which the different liarmless error tests constrain the appellate court, and to consider whether any test better limits the appellate court's discretion than the overwhelming-evidence test.

This Comment discusses the different tests of harmless error endorsed by the Supreme Court and how these tests accord with the proper role of the appellate court. Part I sets out the doctrinal history that led to the current disparate tests of harm. An analysis of cases decided under the different tests is offered, showing that the textual differences between tests translate into actual differences in practice and result. Part II discusses the proper role of the trial court versus the appellate court in a criminal case, and the manner in which the different harmless error tests may cause an appellate court to diverge from its deferential role regarding factfinding. Drawing on the practical and theoretical analyses of Parts I and II, Part III argues that the overwhelming-evidence approach to harmless error review is mucl too permissive of appellate activism, whereas the contribution-to-conviction approach preserves the appellate court's well-justified deferential role regarding findings of guilt.

\section{The Different Tests of Harmless Error}

The harm of a trial error can be analyzed in one of two broad ways. Under an error-focused approach, an error is deemed harmful if it had some impact on the verdict. Under an evidence-focused approach, even if an error had an impact on the verdict, it will not be deemed harmful if there is sufficient properly admitted evidence to support a finding of guilt. In its harmless error jurisprudence, the Supreme Court has endorsed both general approaches to measuring harm. ${ }^{34}$

On the one hand, the Court has said an error is harmful if it likely exerted any influence on the verdict. Harm is assessed under this approach using a contribution-to-conviction test: can the reviewing court say, beyond a reasonable doubt, that the error did not contribute to the guilty verdict? On the other hand, the Court has said an error is harmful only if it was necessary to conviction. Harm is assessed under this approach using an overwhelming-evidence-of-guilt test: is the evidence of guilt so strong that the error was essentially irrelevant to conviction? While the contribution-

33. For examples of this extreme indeterminacy position, see Anthony D'Amato, Pragmatic Indeterminacy, 85 Nw. U. L. REv. 148 (1990); Anthony D'Amato, Can Any Legal Theory Constrain Any Judicial Decision?, 43 U. Miam L. Rev. 513 (1989).

34. See Blume \& Garvey, supra note 5, at 176-82 (discussing the Court's use of both errorfocused and outcome-focused versions of the harmless error test); Linda E. Carter, Harmless Error in the Penalty Phase of a Capital Case: A Doctrine Misunderstood and Misapplied, 28 GA. L. REv. 125, 134-35 (1993) ("In some cases, the Supreme Court has focused on whether the erroneously imcluded or excluded evidence 'contributed' to the verdict. In other cases, the Court has emphasized whether the properly admitted evidence was 'overwhelming.' ") (footnote omitted). 
to-conviction test would deem an error harmful unless it was relatively trivial, the overwhelming-evidence test would deem an error harmful only when the overall case against the defendant was relatively weak.

\section{A. Ambiguity in the Court's Harmless Error Decisions Since Chapman}

The relatively short history of the harmless error test has been one of considerable confusion. ${ }^{35}$ When the Chapman Court first announced in 1967 that a constitutional violation may be a harmless error, the Court defined "harmless" to mean that the government has "prove[d] beyond a reasonable doubt that the error complained of did not contribute to the verdict obtained."36 Stated in terms of erroneously admitted evidence, "harmless" meant that there was no "reasonable possibility that the evidence complained of might have contributed to the conviction." "37 After giving content to the phrase "harmless error," the Court stated that "before a federal constitutional error can be held harmless, the court must be able to declare a belief that it was harmless beyond a reasonable doubt."38

This holding plainly incorporated the definition of harm into what it meant for an error to be harmless beyond a reasonable doubt. ${ }^{39}$ But the definition of harm was not explicitly placed in the holding, and consequently, courts have repeatedly rentoved the holding from its definitional context and have interpreted Chapman to mean only that the constitutional error must be "harmless beyond a reasonable doubt."40 The courts doing so have devised their own definition of harmless error or have left their specific standard undeclared. ${ }^{41}$

Because the Court intended to incorporate the definition of harm into the holding, the standard of certainty established in Chapman is a very strict one. Only "small errors or defects that have little, if any, likelihood of

35. This section traces the textual history of the American harmless constitutional error doctrine since its beginning in Chapman v. California, 386 U.S. 18 (1967). For a more detailed history of the harmless error doctrine, including English origins, see Roger J. TRAYNoR, The RIdDLE of Harmless ERROR 3-15 (1970); Goldberg, supra note 19, at 422-32.

36. Chapman, 386 U.S. at 24.

37. Id. (quoting Fahy v. Connecticut, 375 U.S. 85, 86-87 (1963)). The Court made it clear that in restating the test of harm in terms applicable to all errors, and not just to errors in evidence, it was not deviating from the meaning of the Fahy test. Id. The Court noted there was "little, if any, difference" between the two statements of the test. Id.

38. Id.

39. Given that the holding sentence directly follows the definitional sentence, the Court likely saw the incorporation as so obvious that it was unnecessary to repeat the definition in the holding sentence. Moreover, the Court made the intended incorporation clear by stating that this holding simply "adhere[d] to the meaning of our Fahy case." Id. Furthermore, a possible opposing approach that emphasizes the weight of evidence of guilt was rejected: "[T] California courts have neutralized [their harmless error rule] to some extent by emphasis, and perhaps overemphasis, upon the court's view of 'overwhelming evidence.' We prefer the approach of this Court in deciding what was harmless crror in our recent case of Fahy v. Connecticut." Id. at 23 (citation and footnote omitted).

40. See, e.g., United States v. Rodriguez, 943 F.2d 215, 218 (2d Cir. 1991); Dortch v. O'Leary, 863 F.2d 1337, 1344-45 (7th Cir. 1988), cert. denied, 490 U.S. 1049 (1989).

41. See infra text accompanying notes 84-87. 
having changed the result of the trial" were meant to be harmless errors. ${ }^{42}$ The errors in Chapman were clearly not trivial and so were deemed harmful. ${ }^{43}$

The first opinion to deviate from Chapman's definition of harm came within two years. In Harrington v. California, ${ }^{44}$ Justice Douglas, writing for the Court, framed the harmless error test in terms of whether "overwhelming" untainted evidence existed in the record to support a defendant's conviction. ${ }^{45}$ If so, the error could be judged "harmless beyond a reasonable doubt" in accord with Chapman. ${ }^{46}$ Applying this test, the Court ruled that the admission of evidence in violation of Bruton $v$. United States ${ }^{47}$ was harmless error because not only was the erroneously-admitted evidence "cumulative," but other evidence of guilt was "overwhelming."48

The meaning of Justice Douglas' overwhelming-evidence standard was vague, and thus it was unclear how strict this test was meant to be. The dissent, however, perceived the shift in focus from the nature of the error to the overall strength of the case to be a relaxation of the harmless error standard:

Chapman ... meant no conıproinise with the proposition that a conviction cannot constitutionally be based to any extent on constitutional error. The Court today by shifting the inquiry from whether the constitutional error contributed to the conviction to whether the untainted evidence provided "overwhelming" support for the conviction puts aside the firm resolve of Chapman . . . .49

To the dissent's comments Justice Douglas responded: "We do not depart from Chapman; nor do we dilute it by inference. We reaffirm it."so Despite the Court's "reaffirmation" of Chapman, the majority opinion provided no analysis of what impact the erroneous evidence umight have had on the verdict-an analysis Chapman seems to require. ${ }^{51}$ Nevertheless,

42. Chapman, 386 U.S. at 22.

43. In Chapman, the prosecutor repeatedly commented on the defendants' failure to testify at trial, and the trial judge instructed the jury that it could draw an adverse inference from this failure to testify. Id. at 19. The Califomia Supreme Court ruled that these comments and the instruction were harmless errors even though they violated Griffin v. Califomia, 380 U.S. 609 (1965), which assures that a person may refuse to give testimony against him or herself without penalty. Chapman, 386 U.S. at 19-20. In reversing, the U.S. Supreme Court emphasized the pervasive effect of these errors on the proceedings. Id. at 24-26. Indeed, the Court concluded that, "absent the constitutionally forbidden comments, honest, fair-minded jurors might very well have brought in not-guilty verdicts." Id. at 25-26.

44. 395 U.S. 250 (1969).

45. Id. at 254.

46. Id.

47. 391 U.S. 123, 126 (1968) (holding that the admission of the confession of a codefendant who does not take the stand is a violation of the Confrontation Clause of the Sixth Amendment).

48. Harrington, 395 U.S. at 254.

49. Id. at 255 (Brennan, J., dissenting).

50. Id. at 254 .

51. See id. at 255 (Brennan, J., dissenting) ("[In Chapman] we left no doubt that for an error to be 'harmless' it must have made no contribution to a criminal conviction."); see also Sullivan v. Louisiana, 113 S. Ct. 2078, 2081-82 (1993) (indicating that this is indeed what is required under Chapman). 
because of Justice Douglas' clear refusal to overrule Chapman, Harrington's new definition of harm coexisted with Chapman's definition.

The Court acted quickly to ensconce the harmless error definition employed in Harrington.. Within four years, three opinions embraced this new definition. The first case, Schneble $v$. Florida, ${ }^{52}$ again concerned a Bruton violation, and again the Court found the error harmless. In setting out the standard for judging harm, the Court interpreted the Chapman contribution-to-conviction test to accord with the overwhelming-evidence test. The Court said:

The mere finding of a violation of the Bruton rule in the course of the trial, however, does not automatically require reversal of the ensuing criminal conviction. In some cases the properly admitted evidence of guilt is so overwhelming, and the prejudicial effect of the codefendant's admission is so insignificant by coniparison, that it is clear beyond a reasonable doubt that the improper use of the admission was harmless error. ${ }^{53}$

Thus, the focus was not on whether the codefendant's admission might have had an impact on the verdict. Instead, the Court interpreted the contribution-to-conviction standard to nean that a jury would have convicted in the absence of the erroneous evidence. ${ }^{54}$ Justice Marshall dissented from the Court's application of the harmless error test, arguing that "[u]nless the Court intends to emasculate Bruton ... or to overrule Chapman $v$. California, ... then I submit that its decision is clearly wrong."s5

In Brown v. United States, ${ }^{56}$ yet another case involving a Bruton violation, the overwhelming-evidence test received further support. The Court determined that the erroneous evidence was "nierely cumulative of other overwhelming and largely uncontroverted evidence properly before the jury." 57 Thus, "[i]n this case, as in Harrington $v$. California, the independent evidence 'is so overwhelming that unless we say that no violation of Bruton can constitute harmless error, we must leave this . . . conviction undisturbed." "58

The Court first endorsed the Harrington test in a non-Bruton case in

52. 405 U.S. 427 (1972).

53. Id. at 430 .

54. The Court first cited to Chapman and then reinterpreted it:

[U]nless there is a reasonable possibility that the inproperly admitted evidence contributed to the conviction, reversal is not required. See Chapman v. California, 386 U.S. 18, 24 (1967). In this case, we conclude that the "minds of an average jury" would not have found the State's case significantly less persuasive had the testimony as to Snell's admissions been excluded. The admission into evidenee of these statements, therefore, was at most harmless error.

Schneble, 405 U.S. at 432 (citation omitted).

55. Id. at 437 .

56. 411 U.S. 223 (1973).

57. Id. at 231.

58. Id. (ellipsis in original) (citations omitted) (quoting Harrington v. California, 395 U.S. 250, 254 (1969)). 
Milton v. Wainwright. ${ }^{59}$ Petitioner Milton claimed that his Fifth and Sixth Amendment rights were violated when an undercover officer posed as Milton's cellmate to obtain a confession. ${ }^{60}$ The Court did not rule on whether a constitutional violation had occurred, but simply held that if any error did occur, it was harmless. ${ }^{61}$ The Court based this conclusion on its assessment that "[t]he jury, in addition to hearing the challenged testimony, was presented with overwhelming evidence of petitioner's guilt." 62 This analysis allowed the Court to opine that the error "was, beyond reasonable doubt, harmless." ${ }^{23}$ The Court nowhere asserted that the error did not, beyond a reasonable doubt, contribute to the conviction.

Subsequent cases have not resolved this confusion; both the Chapman and Harrington variants of the harmless error test are continually invoked. For instance, in United States v. Hasting ${ }^{64}$ the Court repeated the familiar pattern of Harrington, finding overwhelming evidence of guilt and therefore declaring the error harmless beyond reasonable doubt. ${ }^{65} \mathrm{Yet}$, in Satterwhite v. Texas, ${ }^{66}$ the Court employed the Chapman test ${ }^{67}$ and held that the error was not harmless because it was "impossible to say beyond a reasonable doubt that [the error] . . . did not influence" the outcome. ${ }^{68}$

Instead of clarifying this issue in recent years, the Court, in Delaware v. Van Arsdall, ${ }^{69}$ added to the disorder by creating a hybrid of the above two tests. Van Arsdall presented the question of whether an unconstitutional restriction of defendant's right to cross-examine a prosecution witness was harmless. The Court held that the proper inquiry was

whether, assuming that the damaging potential of the cross-examination were fully realized, a reviewimg court might nonetheless say that the error was harmless beyond a reasonable doubt. Whether such an error is harmless in a particular case depends upon a host of factors, all readily accessible to reviewing courts. These factors include the importance of the witness' testimony in the prosecution's case, whether the testimony was cumulative, the presence or absence of evidence corroborating or contradicting the testimony of the witness on material points, the extent of cross-examination

59. 407 U.S. 371 (1972).

60. Id. at 372 .

61. Id. ("Assuming, arguendo, that the challenged testimony should have been excluded, the record clearly reveals that any error in its admission was harmless beyond a reasonable doubt.").

62. Id. at 372-73.

63. Id. at 378 .

64. 461 U.S. 499 (1983).

65. Id. at 510-12.

66. 486 U.S. 249 (1988).

67. See id. at 258-59 ("The question . . . is not whether the legally admitted evidence was sufficient to support the death sentence . . but rather, whether the State has proved "heyond a reasonable doubt that the error complained of did not contribute to the verdict obtained.' ").

68. Id. at 260 .

69. 475 U.S. 673 (1986). 
otherwise permitted, and, of course, the overall strength of the prosecution's case. ${ }^{70}$

This test thus directs a court to compare the importance of the erroneous testimony to the weight of the other evidence received. The line between the overwhelming-evidence test and the contribution-to-conviction test is blurred to the extent that a reviewing court is now told to consider both the "tainted" and "untainted" evidence. No longer is the erroneous, "tainted" evidence the sole determinant of whether the error is harmless. The line between the Chapman and Harrington standards is obliterated to the extent that the importance of the error simply becomes one factor in the calculation of whether overwhelming evidence of guilt exists.

During the October, 1990 term the Court had the opportunity to end this confusion, but declined to do so. In Yates $v$. Evatt, ${ }^{71}$ the Court considered whether an unconstitutional burden-shifting jury instruction that created a presumption of malice was harmless. Although the Court painstakingly set out the method for assessing harm under Chapman, ${ }^{72}$ making clear that the Chapman approach is very strict and confined, ${ }^{73}$ it did not, in the end, apply the Chapman test. Instead, it appears that the Court reverted to a version of the hybrid balancing approach. ${ }^{74}$

The sum of the Court's activity since Chapman is that the harm of constitutional errors may be evaluated under either of two textually-distinct tests, or under a hybrid of the two. ${ }^{75}$ Lower court decisions evince this state of confusion: both federal and state courts ${ }^{76}$ continue to apply the contribu-

70. Id. at 684. Likewise, the Court in Harrington v. California alluded to the fact that the evidence in that case was cumulative, and in the next sentence concluded that the error was harmless because the evidence of guilt was overwhelming. 395 U.S. 250, 254 (1969). Professor Field argues that a harmless error test may be fashioned that turns solely on whether erroneous evidence was cumulative. See Martha A. Field, Assessing the Harmlessness of Federal Constitutional Error-A Process in Need of a Rationale, 125 U. PA. L. REv. 15, $37-58$ (1976). But see David M. Skoglind, Comment, Harmless Constitutional Error: An Analysis of lis Current Application, 33 BAYLOR L. REv. 961, 966-67 (1981) (discussing problems with a cumulative evidence test).

71. 500 U.S. 391 (1991), overruled on other grounds by Estclle v. McGuire, 502 U.S. 62 (1991).

72. Id. at $402-06$.

73.

To satisfy Chapman's reasonable doubt standard, it will not be enough that the jury considered evidence from which it could have come to the verdict without reliance on the [erroneous] presumption. Rather, the issue under Chapman is whether the jury actually rested its verdict on evidence estabhishing the presumed fact beyond a reasonable doubt, independently of the presumption.

Id. at 404.

74. See id. at 404-05 (stating that a court must "weigh" the evidence of guilt and decide whether it is "so overwhelming as to leave it beyond a reasonable doubt that the verdict . . . would have been the same" without the error).

75. See Field, supra note 70 , at 32 ("[C]ase law on the content of the harmless error standard is less than lucid."); Saltzburg, supra note 5, at 988 ("Chaos surrounds the standard for appellate review of errors in criminal proceedings."). These observations remain valid today-some 20 years later.

76. The Chapman Court determined that the standard for judging the harm of federal eonstitutional errors was a matter of federal law regardless of whether the violation occurred in a federal or state court. 386 U.S. 18, 21 (1967). Thus, state variation in judging federal constitutional error may not be sustained on federalisin grounds. To the extent that states choose a rule that makes affirmance 
tion-to-the-conviction, ${ }^{77}$ overwhelming-evidence, ${ }^{78}$ and hybrid ${ }^{79}$ variants of the harmless error test.

\section{B. A Practical Comparison of the Tests: Do They Produce Different Outcomes?}

The textual differences in these harmless error tests are irrelevant unless they translate into differences in application and result. If these different tests are mere "labels reflecting the inadequacy of one verbal formula for capturing the same standard of subjective certainty," should sound not over the disparity in textual definitions, but rather over the disconnection between stated and imposed law. To explore this question of semantic versus substantive difference, I compared the results of numerous harmless error cases to see whether cognizable patterns emerged. ${ }^{81}$ This inquiry was focused not simply on which harmless error test the court

more difficult, while still satisfying due process requirements, they are free to deviate from the Court's specific rule. See Delaware v. Van Arsdall, 475 U.S. 673, 689 (1986) (Marshall, J., dissenting) ("[T]his Court cannot require state courts to apply harmless-error analysis to violations of the Federal Constitution. ... . When the Constitution does not mandate a particular remedy, this Court may not 'declare which of many admittedly constitutional [remedial] alternatives a State may choose.' " (second alteration in original) (citation omitted)).

77. See, e.g., United States v. Szymaniak, 934 F.2d 434, 440 (2d Cir. 1991) (Miranda violation); United States v. Vargas, 933 F.2d 701, 709-10 (9th Cir. 1991) (Sixth Amendment violation); Kordenbrock v. Scroggy. 919 F.2d 1091, $1097-1100$ (6th Cir. 1990) (en banc) (Miranda violation), cert. denied, 499 U.S. 970 (1991); Fleming v. Collins, 917 F.2d 850, 855-57 (5th Cir. 1990) (Miranda violation), reh'g granted, 927 F.2d 824 (1991) (en banc); United States v. North, 910 F.2d 843, 892-94 (D.C. Cir. 1990) (improper jury instruction), cert. denied, 500 U.S. 941 (1991); Walker v. State, 795 P.2d 1064, 1069 (Okla. Crim. App. 1990) (Fifth Amendment violation); Satter v. Solem, 458 N.W.2d 762, 769-70 (S.D. 1990) (Miranda violation); Higginbotham v. State, 807 S.W.2d 732, 733-38 (Tex. Crim. App. 1991) (en banc) (Fifth Amendment violation).

78. See, e.g., Hunter v. Clark, 934 F.2d 856, 859-64 (7th Cir.) (failure to give requested instruction that jury may not draw an adverse inference from defendant not testifying), cert. denied, 112 S. Ct. 388 (1991); United States v. Valley, 928 F.2d 130, 135 (5th Cir. 1991) (improper comments by prosecutor); Bartley v. People, 817 P.2d 1029, 1034-35 (Colo. 1991) (en banc) (Fourth Amendment violation); State v. Shiffiett, 508 A.2d 748, 765-67 (Conn. 1986) (Fourth and Fifth Amendment violations and improper jury instruction); James v. Commonwealth, 679 S.W.2d 238, 239-40 (Ky. 1984) (failure to provide requested instruction that no adverse inferences may be drawn from defendant not testifying), cert. denied, 470 U.S. 1086 (1985); Brodniak v. State, 779 P.2d 71, 73-75 (Mont. 1989) (Sixth Amendment Violation).

79. See, e.g., United States v. McMahon, 938 F.2d 1501, 1505-07 (1st Cir. 1991) (erroneous denial of access to grand jury testimony); United States v. Copley, 938 F.2d 107, 110-11 (8th Cir. 1991) (Sixth Amendment violation); Marcum v. Knight, No. 89-6192, 1991 U.S. App. LEXIS 355, at *4-7 (6th Cir. Jan. 8, 1991) (Sixth Amendment violation); United States v. Lang, 904 F.2d 618, 625-27 (11th Cir.) (Sixth Amendment violation), cert. denied, 498 U.S. 924 (1990); Brecht v. Abrahamson, 759 F. Supp. 500, 507-08 (W.D. Wis.) (improper references to post-Miranda silence of defendant), rev'd, 944 F.2d 1363 (7th Cir. 1991), aff'd, 113 S. Ct. 1710 (1993); Brodniak, 779 P.2d at 76 (Hunt, J., dissenting) (Sixth Amendment violation).

80. Michael R. Fruehwald, Note, Miranda Warnings and the Harmless Error Doctrine: Comments on the Indiana Approach, 47 IND. L.J. 331, 333 n.16 (1972).

81. Professor Carter conducted a cursory review of Supreme Court cases, concluding that the tests do lead to different results. See Carter, supra note 34, at 137-38 \& nn.62-63. A broader and more thorough review is undertaken here. 
named in its decision, but on which test it actually applied in its analysis. ${ }^{82}$ This assessment emphasized how the court investigated the trial record and the quantum of proof that seemed to guide judicial decisionmaking. For example, merely reciting the Chapman holding would be insufficient to place a case and its result under this test. Rather, to be categorized as a case using the contribution-to-conviction test, the court's opinion needed to emphasize two things: the impact of the error on the verdict, as opposed to the weight of untainted evidence, and a strict standard of proof. ${ }^{83}$

This survey sought to provide illustrative rather than definitive statements about the operation of the harmless error doctrine. That is, the examination of cases and the conclusions drawn from that examination are necessarily imprecise. The analysis of judicial opinions is fraught with uncertainty about a court's forthrightness and clarity: important factors in the decisionmaking process may not be captured on the record. Any survey of this sort necessarily proceeds on the assumption that an opinion at least approximates a court's reasoning process. These limits notwithstanding, some enlightening observations can be made.

First, courts often conflate the contribution-to-conviction and overwhelming-evidence tests, ${ }^{84}$ as occurred in Harrington. The Second Circuit,

82. Cases were selected without regard to whether the court affirmed or reversed the appellant's conviction. To supplement the Supreme Court and other cases already collected, electronic searches were utilized to find appropriate cases. Key words included "harmless error," "constitutional violation," "overwhelming evidence," "contribut! to conviction," and "Van Arsdall." The first twenty or so cases located within the respective categories were used.

The lesser number of Chapman and Van Arsdall cases is due to the greater difficulty in finding cases where the contribution-to-conviction and balancing tests are actually applied. In locating cases, the number of overwhelming evidence cases quickly outnumbered the other two types of cases found. It appears, therefore, that the overwhelming evidence test predominates in frequency of application. A recent search of the ALLFEDS file in Westlaw is illustrative. The search "date(aft I992) and contribut! /p "harmless error" " found 41 documents, whereas the search "date(aft 1992) and overwhelm/ /p "harmless error" " found 82 documents. Of course, not every document found is a harmless error case decided under Chapman or Harrington, but the search results suggest a greater recognition of the overwhelming evidence brand of harmless error review. At the least, the overwhelming nature of evidence in a harmless error case is discussed more often than the likelihood that a piece of evidence contributed to the conviction.

83. See infra Part II (discussing the differences in process of review and burdens of persuasion under the various tests).

84. See United States v. Rodriguez, 943 F.2d 215, 218 (2d Cir. 1991) ("II]n light of the overwhelming evidence of the defendant's guilt, the error did not contribute to the verdict and is harmless beyond a reasonable doubt."); United States v. Valley, 928 F.2d 130, 135 (5th Cir. 1991) ("In the light of this [overwhelming] evidence, we find ... "beyond a reasonable doubt that the error complained of did not contribute to the verdict obtained.' " (quoting Chapman v. California, 386 U.S. 18, 24 (1967)); Hunter v. Clark, 906 F.2d 302, 309 (7th Cir. 1990) ("We are convinced that because of the overwhelming evidence of guilt, [the error] had no impact on the jury verdict."), vacated, No. 89 . 2594, 1990 U.S. App. LEXIS 16647 (7th Cir. Sept. I7, I990), on reh'g, 934 F.2d 856, 860 (7th Cir.) (cn banc) ("[E]vidence in this case was so convincing that even if the trial judge had given the requested ... . instruction, it would not have affected the jury's verdict."), cert. denied, 112 S. Ct. 388 (1991); United States v. Pena, 897 F.2d 1075, 1082-83 (11th Cir. 1990) (citing contribution test but then applying overwhelmingness test); State v. Shifflett, 508 A.2d 748, 765-66 (Conn. 1986) ("Because the admissible evidence at trial . . . was overwhelming, we hold that the admission into evidence of the fruits of the 
for instance, has declared that overwhelming evidence of guilt indicates that an error did not contribute to the conviction. ${ }^{85}$ The Chapman contribution test, however, directs one away from the overwhelmingness of evidence to the error's likely impact. As one commentator noted, "[o]verwhelming evidence may provide support, even conclusive support, for holding the error harmless, but it is not invariably conclusive." asks whether an error

played a substantial part in the deliberation of the [reasonable] jury and thus contributed to the actual verdict reached, for the jury may have reached its verdict because of the error without considering other reasons untainted by error that would have supported the same result. ${ }^{87}$

In equating contribution-to-conviction with overwhelming evidence, a court loses Chapman's unique perspective on error. The practical lesson to be drawn here is that one cannot simply assume that because a court cites a particular test it actually applied that test. A more careful reading is required to discern what analysis the court has employed.

Second, when one focuses on what test in fact controls the analysis, one finds that defendants generally have a greater chance of reversal under the Chapman test. Of seventeen cases identified as applying the contribution-to-the-conviction test, only one (5.9\%) resulted in a finding of harmless error. ${ }^{88}$ In contrast, twenty of twenty overwhelming-evidence cases $(100 \%)$ resulted in a finding of harmless error, ${ }^{89}$ and twelve of seventeen

[impermissible] search could not possibly have affected the jury's judgment in this case."); Brodniak v. State, 779 P.2d 71, 74 (Mont. 1989) ("The overwhelming evidence rule is one method used by this Court to ascertain whether there is a reasonable possibility that the inadmissible evidence contributed to the verdict.").

85. See Rodriguez 943 F.2d at 218.

86. TRAYNOR, supra note 35 , at 22 .

87. Id.

88. The cases classified as applying the Chapman test, and the pages on which the liarmless error analysis is reported, are: Arizona v. Fulminante, 499 U.S. 279, 295-302 (1991) (error not harmless); Satterwhite v. Texas, 486 U.S. 249, 258-60 (1988) (not harmless); Chapman v. California, 386 U.S. 18, 24-26 (1967) (not harmless); United States v. Jones, 982 F.2d 380, 384-85 (9th Cir. 1992) (not harmless); Collazo v. Estelle, 940 F.2d 411, 423-26 (9th Cir. 1991) (en banc) (not harmless), cert. denied, 112 S. Ct. 870 (1992); Ouimette v. Moran, 942 F.2d 1, 11-12 (1st Cir. 1991) (not liarmless); United States v. Szymaniak, 934 F.2d 434, 440 (2d Cir. 1991) (not harmless); United States v. Vargas, 933 F.2d 701, 709-10 (9th Cir. 1991) (not liarmless); Kordenbrock v. Scroggy, 919 F.2d 1091, 10971100 (6th Cir. 1990) (en banc) (not harmless), cert. denied, 499 U.S. 970 (1991); Fleming v. Collins, 917 F.2d 850, 855-57 (5th Cir. 1990) (not larmless), reh'g granted, 927 F.2d 824 (1991) (en banc); United States v. Khoury, 901 F.2d 948, 960-61 (11th Cir. 1990) (not harmless); United States v. Reiter, 897 F.2d 639, 644 (2d Cir.) (applying "reasonable probability of prejudice" standard to find the error not harmless), cert. denied, 498 U.S. 817 (1990); Horner v. Ylst, No. C-90-0114 FMS, 1991 U.S. Dist. LEXIS 8931, at *7-8 (N.D. Cal. June 24, 1991) (harmless); United States ex rel. Hanrahan v. Thieret, 748 F. Supp. 603, 608-12 (N.D. III. 1990) (not harmless), rev'd, 933 F.2d 1328 (7th Cir.), cert. denied, 112 S. Ct. 446 (1991); Walker v. State, 795 P.2d 1064, 1069 (Okla. Crim. App. 1990) (not harmless); Satter v. Solem, 458 N.W.2d 762, 769-70 (S.D. 1990) (not harmless); Higginbotham v. State, 807 S.W.2d 732, 733-38 (Tex. Crim. App. 1991) (not harmless).

89. The cases classified as applying the Harrington test, and the pages on which the harmless 
Van Arsdall cases (70.6\%) resulted in harmless error. ${ }^{90}$ of course, these numbers should be cautiously evaluated, but their sheer disparity does suggest that application of the Chapman test makes a new trial considerably more likely.

The difference in reversal rate cannot be attributed to an increased application of the Chapman test to errors whose effects tend to be significant, like improperly admitted confessions. Courts applied each of the tests to a wide range of errors; no pattern of application by type of error was evident. ${ }^{91}$ Furthermore, the outcomes did not depend on the type of crime underlying a case. One might suspect, for example, that the more heinous an offense, the less likely a new trial, but no offense-specific patterns that might explain the differential in reversal rates were apparent.

error analysis is reported, are: United States v. Hasting, 461 U.S. 499, 507-12 (1983) (error harmless); Brown v. United States, 411 U.S. 223, 230-32 (1973) (harmless); Milton v. Wainwright, 407 U.S. 371, 372-73, $377-78$ (1972) (harmless); Schneble v. Florida, 405 U.S. 427, 430-32 (1972) (harmless); Harrington v. California, 395 U.S. 250, $251-54$ (1969) (harmless); United States v. Wilson, 11 F.3d 346, 351 (2d Cir. 1993) (harmless), cert. denied, 114 S. Ct. 2142 (1994); United States v. Innamorati, 996 F.2d 456, 475-77 (1st Cir. 1993) (harmless); Hines v. Sumner, No. 90-15729, 1991 U.S. App. LEXIS 20617, at *2-4 (9th Cir. Aug. 26, 1991) (harmless); United States v. Williams, No. 90-50272, 1991 U.S. App. LEXIS 21116, at *7-8 (9th Cir. Aug. 22, 1991) (harmless); United States v. Rodriguez, 943 F.2d 215, 218 (2d Cir. 1991) (harmless); Clark v. Moran, 942 F.2d 24, 26-33 (1st Cir. 1991) (harmless); United States v. Valley, 928 F.2d 130, 135 (5th Cir. 1991) (harmless); Hunter v. Clark, 906 F.2d 302, 308-10 (7th Cir. 1990) (harmless), vacated, No. 89-2594, 1990 U.S. App. LEXIS 16647 (7th Cir. Sept. 17, 1990), on reh'g, 934 F.2d 856 (7th Cir.) (en banc) (harmless), cert. denied, 112 S. Ct. 388 (1991); United States v. Pena, 897 F.2d 1075, 1082-83 (11th Cir. 1990) (harmless); Dortch v. O'Leary, 863 F.2d 1337, 1344-45 (7th Cir. 1988) (harmless), cert. denied, 490 U.S. 1049 (1989); Rock v. Zimmerman, 729 F. Supp. 398, 406-09 (M.D. Pa. 1990) (harmless), aff'd, 959 F.2d 1237 (3d Cir.), cert. denied, 112 S. Ct. 3036 (1992), disapproved by Brecht v. Abrahamson, 113 S. Ct. 1710, 1716-22 (1993) (holding that the test announced in Kotteakos v. United States, 328 U.S. 750 (1946), rather than the Chapman test, governs habeas corpus cases); Bartley v. People, 817 P.2d 1029, 1034-35 (Colo. 1991) (harmless); State v. Shifflett, 508 A.2d 748, 765-67 (Conn. 1986) (harmless); James v. Conmonwealth, 679 S.W.2d 238, 239-40 (Ky. 1984) (harmless), cert. denied, 470 U.S. 1086 (1985); Brodniak v. State, 779 P.2d 71, 7375 (Mont. 1989) (harmless).

90. To be classified as a hybrid case, an opinion must engage in a balancing of the error's impact against the weight of the untainted evidence. The cases so classified, and the pages on which the harmless error analysis is reported, are: United States v. Veltmann, 6 F.3d 1483, 1500-01 (11th Cir. 1993) (error not harmless); United States v. McMahon, 938 F.2d 1501, 1505-07 (1st Cir. 1991) (harmless); United States v. Smith, No. 90-5787, I991 U.S. App. LEXIS 15112, at *8-11 (4th Cir. July 15, 1991) (harmless); United States v. Copley, 938 F.2d 107, 110-11 (8th Cir. 1991) (harmless); United States v. Perkins, 937 F.2d 1397, 1403-04 (9th Cir. 1991) (harmless); Marcum v. Knight, No. 89-6192, 1991 U.S. App. LEXIS 355, at *4-7 (6th Cir. Jan. 8, 1991) (harmless); United States v. Thompson, 908 F.2d 648, 652-53 (10th Cir. 1990) (not harmless); United States v. Lang, 904 F.2d 618, 625-27 (11th Cir.) (harmless), cert. denied, 498 U.S. 924 (1990); Brecht v. Abrahamson, 759 F. Supp. 500, 507-08 (W.D. Wis.) (not harmless), rev'd, 944 F.2d 1363 (7th Cir. 1991), aff'd, 113 S. Ct. 1710 (1993); United States v. Roshko, No. 90-CR-265 (JAR), 1991 U.S. Dist. LEXIS 1495, at *8-15 (S.D.N.Y. Fcb. 7, 199I) (not harmless), aff'd in part and remanded in part, 969 F.2d 1 (1992); Odle v. Vasquez, 754 F. Supp. 749, $768-69$ (N.D. Cal. 1990) (harmless); Clark v. Moran, 749 F. Supp. 1186, 1192-99 (D.R.I. 1990) (harmless), aff'd, 942 F.2d 24 (1st Cir. 1991); Jarreau v. State, 722 S.W.2d 565, 566-67 (Ark. 1987) (harmless); Numan v. State, 722 S.W.2d 276, $277-79$ (Ark. 1987) (harmless); Commonwealth v. Percz, 581 N.E.2d 1010, 1017-18 (Mass. 1991) (harmless); Commonwealth v. Mahdi, 448 N.E.2d 704, 714-15 (Mass. 1983) (not harmless); State v. Walton, 809 P.2d 81, 87-88 (Or. 1991) (harmless). 79.

91. For a comparison of the diversity of errors to which each test is applied, see supra notes 77- 
The third observation that may be made is that, for those courts that balanced the impact of the error versus the overwhelmingness of untainted evidence - the hybrid test - reversal was typically associated with a finding of the error's harmful impact rather than a lack of overwhelming evidence. ${ }^{92}$ Conversely, affirmance was typically associated with a fiuding of overwhelming evidence rather than the harmless impact of the error. ${ }^{93}$ It is impossible to say whether this is simply a function of the facts of the specific cases, or whether it is an indication of the focus of the courts' attention. It is notable, however, that this pattern rephicates the conclusion above that reversal is more likely under Chapman and affirmance is more likely under Harrington.

Finally, disagreement about an error's harmful or harmless nature is common. Although unanimity frequently occurs, it is not rare to find, within the same case, disagreement over whether an error is harmless or harmful..$^{94}$ Kordenbrock $v$. Scroggy ${ }^{95}$ illustrates how the different tests may be responsible for these differences of opinion. Kordenbrock was decided en banc by the Sixth Circuit, meaning that thirteen different judges considered the case. ${ }^{96}$ Seven of the thirteen judges found that the erroneous admission of a confession was harmful; these judges focused on the likely impact of the error on the verdict. ${ }^{97}$ In contrast, six of the thirteen judges found the error harmless; these judges, focusing on the untainted evidence of guilt, deemed that evidence overwhelming. ${ }^{98}$ Kordenbrock is thus prototypical of how the differences in the Chapman and Harrington tests often translate into real differences in outcomes.

In conclusion, it appears that the harmless error doctrine is in a state of confusion, at least to the extent that different tests are applied and systematic differences in outcomes result. ${ }^{99}$ Courts applying the Chapman test

92. Compare the cases where the conviction was reversed because the error was deemed harmful, cited supra note 90 . Of these cases, only the Veltmann case produced a harmful error result based primarily on an assessment that the untainted evidence was not overwhelming.

93. Compare those cases where error was deemed harmless, cited supra note 90 . Of these cases, only the McMahon case produced a harmless error result based primarily on an assessment that the error did not contribute to the verdict.

94. See cases cited supra notes 88-90. Compare Harrington v. California, 395 U.S. 250, 251-54 (1969) (majority's analysis of error) and United States v. Perkins, 937 F.2d 1397, 1403-06 (9th Cir. 1991) (majority's analysis of error) with Harrington, 395 U.S. at 255-57 (dissent's analysis of error) and Perkins, 937 F.2d at 1406-09 (dissent's analysis of error).

95. 919 F.2d 1091 (6th Cir. 1990), cert. denied, 499 U.S. 970 (1991).

96. Id. at 1093.

97. See id. at 1097-1100,1133, 1135-36 (opinions endorsing the Chapman test and concluding error was not harmless).

98. See id. at 1124-31 (opinion endorsing the Harrington test and concluding error was harmless).

99. To the extent that this is correct, Justice Stevens' concurring statement in Brecht v. Abrahamson, 113 S. Ct. 1710, 1725 (1993), that "the way we phrase the governing standard is far less important than the quality of the judgment with which it is applied," must be qualified. The way the test is phrased may exert considerable influence on how judgment is exercised. Professor Meltzer's conclusion that "differences in doctrinal formulations of standards of review are elusive in application" is also debatable. Meltzer, supra note 4 , at 37. 
adhere to a strict test of harm, affirming convictions only rarely. Courts applying the Harrington test apply a looser version of harmless error, reversing only when an error was necessary to conviction. However, the differential of affirmance and reversal rates between the Chapman and Harrington tests inay not be solely a function of the relative strictness of the tests. Personal values may influence which test is chosen, with conviction-prone judges choosing the Harrington test because of its grant of greater discretion to review the record. Conversely, reversal-prone judges might choose the Chapman test because it calls for a very strict interpretation.

Alternatively, the likelihood that the Harrington standard will cause affirmance of the verdict below may stem from the test's application: even if a court attempts to apply a strict standard of "overwhelming evidence;" it is the nature of a "but for" test to draw attention away from the error in question and towards alternative causes of the outcome. Thus, an error may be deemed crucial only where the totality of evidence is relatively slight.

Whatever the precise source of the differences in procedure, the tests clearly do produce different results. These differences are more than simply semantic. Therefore, it is worthwhile to consider in more detail why these tests produce different results. The next Part divides the tests' procedural differences into two types: differences in modes of appellate review and differences in the burden of persuasion associated with each test. By contrasting the role of the reviewing court under each of the tests with the ideal role of an appellate court, it becomes apparent that the contribution-to-conviction test better preserves the deferential role of the appellate court concerning matters of fact.

II

\section{Appellate Review of Criminal Verdicts}

Our criminal justice systein operates through a division of labor. Factnal determinations are made at the trial court level, and are to be given great deference on appeal. Appellate review is largely confined to contested legal questions. To be sure, appellate courts can disturb prior findings of fact by deeming a question one of law or one of mixed law and fact, ${ }^{100}$ but where a trial court's conclusion is a finding of fact it is "ordinarily permanent." 101 Therefore, as a general matter, the factfinding process

100. See George C. Christie, Judicial Review of Findings of Fact, 87 Nw. U. L. REv. 14, 14 (1992) ("It seems as if no [Supreme Court] term goes by without a violent disagreement among the members of the Court over whether some trial court determination is a question of law or a mixed question of law and fact, and thus open for re-examination, or a question of fact, whose re-examination is thus foreclosed.").

101. Ruggero J. Aldisert, The Judictal Process: Readings, Materials and Cases 689 (1976). 
occurs solely at the trial level, and appellate review is limited to legal issues.

\section{A. The Role of the Trial Court}

Two primary reasons exist for the great respect given to trial courts' findings of fact. First, the trial court is in the best position to assess the probative value of evidence. ${ }^{102}$ This rationale spans civil and criminal trials. Second is a rationale specific to criminal trials: if criminal juries are truly to sit as the "final arbiter[s] of truth and justice," 103 their factual determinations must be given finality.

Under the first rationale, deference to the factual determinations of trial judges and juries has evolved partially because the trial record often fails to provide a complete picture of the evidence. ${ }^{104}$ The credibility of a wituess may depend greatly on her demeanor, and the meaning of a piece of evidence may be quite unclear out of the total context of a trial. The opportunity to observe firsthand testimony and demonstrations, and the subtleties that accompany sucl evidence, places jurors and trial judges in a mucl better position than appellate judges to assess the facts. ${ }^{105}$ Review of an antiseptic record removes appellate judges from the emotion and intensity that may be crucial to understanding and weighing of testimony. It is impossible to capture in a transcript all of the characteristics of a wituess that go to her credibility. ${ }^{106}$ Moreover, the interpretations to which language may lend itself can abound on review, allowing a judge to pick and choose supporting statements. Judge Batchelder summarizes well the difference between the appellate and trial court experiences:

On the appellate court, nearly all of what the judges see is a rerun of what has first played live and in color in the trial court. But the reruns are condensed, edited, and produced in black-and-white.

The difference between trying a case on the district level court and merely reading the briefs on appeal is only a little less marked than the difference between watching Gone With the Wind and reading the TV Guide description of it. ${ }^{107}$

102. See, e.8., Georgia v. Brailsford, 3 U.S. (3 Dall.) 1, 4 (1794) ("It may not be amiss, here, gentlemen, to remind you of the good old rule, that on questions of fact, it is the province of the jury, on questions of law, it is the province of the court, to decide. ... [F]or as, on the one hand, it is presumed, that juries are the best judges of facts; it is, on the other hand, presumable, that the court[s] are the best judges of law."); Credeur v. Credeur, 423 So. 2d 90, 91 (La. Ct. App. 1982) ("The trial court, which heard the testimony and observed the demeanor of the witnesses, is the best judge of the facts.").

103. United States v. Datcher, 830 F. Supp. 411,415 (M.D. Tenn. 1993).

104. See Goldberg, supra note 19 , at 430.

105. See FED. R. Crv. P. 52(a) (stating that a trial court's findings of fact "shall not be set aside unless clearly erroneous").

106. See id. ("[D]ue regard shall be given to the opportumity of the triai court to judge the credibility of the witnesses.").

107. Alice M. Batehelder, Some Brief Reflections of a Circuit Judge, 54 Oнго ST. L.J. 1453, 1453 (1993). 
This problem is compounded in harmless error cases by the obverse concern that the record may also, in a sense, preserve too much information. Because the record preserves both tainted and untainted evidence, and because this tainted evidence may be very probative of guilt, a judge trying to examine only the untainted evidence may face a very difficult task. Indeed, an assumption that appellate judges can conduct a fair second trial on the basis of "untainted evidence" is problematic in that it assumes that fine distinctions can be drawn between tainted and untainted evidence, when all of this evidence remains in the record as a coherent whole. ${ }^{108}$ Moreover, the isolation of bits, or even large portions, of evidence is an artificial manner in which to conduct a trial. Readiness to believe or disbelieve one piece of evidence may be greatly bolstered by the existence of other evidence. Cases based on circumstantial evidence rely on such networks of evidence. A second "trial" by an appellate court denies the defense and prosecution the chance to construct a compelling story for innocence or guilt based on the new, untainted body of evidence. ${ }^{109}$ Additionally, any second decision about guilt will likely be influenced by the trial's original outcome. ${ }^{110}$ In short, an appellate judginent of guilt supposedly based on an "independent" review of "untainted" evidence inay be less independent and more tainted than inost would suspect. Thus, for numerous reasons related to the nature of the appellate record, trial by appellate court is a dubious event.

Under the second rationale, when an appellate court assumes the role of fact-finder in a criminal case, it usurps the role of the jury, for rightly or wrongly, "jury trials comprise the heart of our criminal justice system." 11

108. Arizona v. Fulminante, 499 U.S. 279 (1991), is telling in this regard. A majority of the justices held that the improper admission of the defendant's coerced confession was harmful, because it was very damning and may have lent credibility to other evidence admitted at trial. A minority of the justices would have held the error harmless, however, because they did not see any relation between the erroneously admitted confession and other evidence in the trial. Hence, the minority saw no taint on the remainder of the trial and would have affirmed on the basis of that other evidence. See also Sara $\mathrm{E}$. Welch, Note, Fifih Amendment-Harmless Error Analysis Applied to Coerced Confessions, 82 J. CRIM. L. \& CrIminology 849,875 (discussing the different views of the majority and minority in Fulminante).

109. "One of the ways parties compete in litigation is by telling stories they hope the decisionmaker will believe." William H. Page, Ideology and the Strictures of Legal Narrative, 68 TuL. L. REv. 1029, 1029 (1994) (book review).

110. The assumption that an appellate court can ignore the lower court finding of guilt is questionable. "When people know how an event turned out, they are usually unable to reproduce the judgments they would have made without outcome knowledge." David Wasserman et al., Hindsight and Causality, 17 Personalrty \& Soc. Psychol. BurL. 30, 30 (1991) (italics omitted). See generally Scott A. Hawkins \& Reid Hastie, Hindsight: Biased Jndgments of Past Events After the Outcomes Are Known, 107 PsYchol. BULL. 311 (1990) (reviewing research on "certainty of hindsight" bias).

111. Goldberg, supra note 19 , at 430 . The central role of juries within our criminal justice system has often been criticized. For an excellent summary and analysis of these critiques, see VALERIB P. HANS \& NEIL VIDMAR, JUdGING THE JURY (1986). Hans and Vidmar ultimately conclude in favor of juries:

Despite some flaws, [the jury system] serves the cause of justice very well. For over 700 years it has weathered criticism and attack, always to survive and to be cherished by the 
A defendant expects to receive judgment from a panel of peers and not from a panel of experienced jurists who may approach questions of guilt in a significantly different manner. Indeed, the defendant may seek to exploit the sympathies of jurors who have not become immune to the pleas of defendants or jaded by repeated encounters with hardened criminals. ${ }^{112}$ This right to invoke public sympathy and opinion is guaranteed by the Sixth Amendment.

A criminal jury trial is a vehicle both for determining guilt and for expressing community values. ${ }^{113}$ If conviction were the only purpose served by a jury trial, then the jury would not have the power to nullify a law or pumshment, ${ }^{114}$ and there would be no prohibition either against directed verdicts of guilt ${ }^{115}$ or against setting aside acquittals. ${ }^{116}$ Furthermore, the use of special interrogatories in criminal cases would not be disfavored, ${ }^{117}$ and inconsistent jury verdicts would not be allowed. ${ }^{118}$

peoples who own it. Adaptability has been the key to its survival. It should remain open to experimentation and modification, but those who would wisl to curtail its powers or abolisli it should bear the burden of proof. Defenders of the jury clearly bave the weight of the evidence on their side.

Id. at 251.

112. See, e.g., United States v. Datcher, 830 F. Supp. 411, 412 (M.D. Tenn. 1993) ("In essence, Mr. Datcher hopes that the jury, when it learns of the draconian sentence hanging over his head, would deem this penalty too great for any offense Mr. Datcher may liave committed and thus let him go free."). Similarly, the Sixth Circuit explained:

The present law of "jury nullification" (the jury's power to acquit a defendant out of refusal to apply the law to facts clearly evidencing a criminal violation) seems . . . to allow a defense attomey some lceway in persuading the jury to acquit out of considerations of mercy or obedience to a higher law.

United States v. Burkhart, 501 F.2d 993, 997 n.3 (6th Cir. 1974), cert. denied, 420 U.S. 946 (1975).

113. See, e.g., Williams v. Florida, 399 U.S. 78, 100 (1970) ("[T]he essential feature of a jury obviously lies in the interposition between the accused and his accuser of the commonsense judgment of a group of laymen, and in the cominurity participation and sliared responsibility that results from that group's determination of guilt or innocence.").

114. See Horning v. District of Columbia, 254 U.S. 135, 138 (1920) ("[T]lie jury has the power to bring in a verdict in the teeth of both law and facts."); Sparf v. United States, 156 U.S. 51, 102, 105-07 (1895); United States v. Wilson, 629 F.2d 439, 443 (6th Cir. 1980); Everctt v. United States, 336 F.2d 979, 986 (D.C. Cir. 1964) (Wright, J., dissenting) ("Justice Gray's dissent in Sparf] reaffirmed the American common law tradition that this was no mere power of the jury, but their proper right."); Lloyd E. Moore, The Jury: TOOL of KIngs, Palladium of Liberty 168 (2d ed. 1988) (discussing a jury's power to apply the law after Sparf).

115. See United States v. Martin Limen Supply Co., 430 U.S. 564, $572-73$ (1977) ("[A] trial judge is prolibited from entering a judgment of conviction or directing the jury to come forward with such a verdict, regardless of how overwhelmingly the evidence may point in that direction.") (citations omitted); United Bhd. of Carpenters \& Joiners of Am. v. United States, 330 U.S. 395, 408 (1947) ("[A] judge may not direct a verdict of guilty no matter how conclusive the evidence.").

116. See FED. R. CRMM. P. 29(c) (only a conviction may be set aside); see also Martin Linen, 430 U.S. at 573 ("The trial judge is . . . barred from attempting to override or interfere with the jurors' independent judgment in a manner contrary to the interests of the accused.").

117. See Wilson, 629 F.2d at 441-44 (explaining why special verdict forms are generally disfavored in criminal cases).

118.

[W] here truly inconsistent verdicts have been reaclied, "[t]he most that can be said . . is that the verdict shows that either in the acquittal or the conviction the jury did not speak to their real conclusions, but that does not show that they were not convinced of the defendant's 
The interposition of juror approval between the state and the accused is designed "to prevent oppression by the Government." 119 Although trial by jury serves many purposes for the jurors and the justice system, ${ }^{120}$ the primary rationale for jury trial has consistently been that it serves as a bulwark against official tyranny. ${ }^{121}$ Indeed, as explained by Alexander Hamilton, the protection offered by a jury trial was one of the unifying forces in the development of the Constitution:

The friends and adversaries of the plan of the convention, if they agree in nothing else, concur at least in the value they set upon the trial by jury; or if there is any difference between them it consists in this: the former regard it as a valuable safeguard to liberty; the latter represent it as the very palladium of free government. ${ }^{122}$

Substantive criminal laws may be misguided, ${ }^{123}$ sentencing laws may be overly harsh, ${ }^{124}$ prosecutions may be selectively imposed, ${ }^{125}$ and judges

guilt." ... [A]s the above quote suggests, ... [i]t is . . . possible that the jury, convinced of guilt, properly reached its conclusion on the compound offense, and then through mistake, compromise, or lenity, arrived at an inconsistent conclusion on the lesser offense. But in such situations the Government has no recourse if it wishes to correct the jury's error; the Government is precluded from appealing or otherwise upsetting such an acquittal by the Constitution's Double Jeopardy Clause.

United States v. Powell, 469 U.S. 57, 64-65 (1984) (quoting Dunn v. United States, 284 U.S. 390, 393 (1932)).

119. Williams v. Florida, 399 U.S. 78, 100 (1970).

120. See, e.g., 2 J. Kendall Few, TrIaL BY JURY 60 (1993) (discussing the benefits of trial by jury, including "preservation of public confidence in the administration of justice, provision for needed fiexibility in legal rules, education of the citizenry in the administration of law[,] and the improvement of the quality of verdicts based on varied temperaments and minds").

121. See, e.g.,. Duncan v. Louisiana, 391 U.S. 145, 156 (1968) ("Fear of unchecked power . . found expression in the criminal law in the insistence upon [jury trials]."); United States ex rel. Toth v. Quarles, 350 U.S. 11, 18-19 (1955) ("On many occasions, . . . jurors-plain people-have manfully stood up in defense of liberty agáinst the importunities of judges and despite prevailing hysteria and prejudices."). See generally Few, supra note 120.

122. The Federalist No. 83, at 139 (Alexander Hamilton) (M. Walter Dunne ed., 1901).

123. For example, some people believe current anti-euthanasia laws to be misguided. See, e.g., Robert J. Jaeger, A Medical Option, CHI. TRIB., Feb, 28, 1993 at C2 (arguing that "there are no credible arguments" for medical-legal prohibitions against euthanasia); Letters to the Editor: 'Frankenstein,' S.F. Chron., Mar. 5, 1993, at A24 (suggesting that current anti-euthanasia laws may be intruding upon individual liberty and choice).

124. As some believe to be the case, for example, with respect to the federal sentencing guidelines and mandatory mimmum sentences. See, e.g., Gerald W. Heaney, The Reality of Guidelines Sentencing: No End to Disparity, 28 AM. CRM. L. REv. 161 (1991) (criticizing guidelines sentencing as being overly harsh both in particular cases and in general); Elizabeth T. Lear, Is Conviction Irrelevant?, 40 UCLA L. REv. 1179 (1993) (attacking the "alleged related offense" provision of the Federal Sentencing Guidelines); David Yellen, Illusion, Illogic, and Injustice: Real-Offense Sentencing and the Federal Sentencing Guidelines, 78 MIN. L. REv. 403 (1993) (same).

125. For examples of alleged selective prosecutions, see Hugo Kugiya, Shelley to Face Assault Charge-Judge Denies Motion to Dismiss the Case, SEAtme TImEs, Oct. 19, 1993, at C5 (detailing case against a Umiversity of Washington football player); Legal or Political? Hutchison Case Set Up to be Fought on That Ground, Houston CHRON., Sept. 28, 1993, at B10 (discussing the trial of United States Senator Kay Bailey Hutchison). See generally P.S. Kane, Comment, Why Have You Singled Me Out? The Use of Prosecutorial Discretion for Selective Prosecution, 67 Tur. L. Rev. 2293 (1993) 
may be biased. ${ }^{126}$ Citizens therefore rely on the common sense and mercy of a jury, through its nullification power, to keep both laws and government officials from working an mjustice.

When appellate courts engage in review of the trial record to arrive at their own, independent judgments of guilt and innocence, they intrude upon the central function of the jury. ${ }^{127}$ Moreover, in contrast to a jury trial, where the fresh eyes of a jury evaluate the case of a particular defendant, appellate review is conducted by judges whose eyes may often be weary from viewing criminal excess and procedural delay.

Strong justifications thus exist, particularly in criminal cases, for the central factfinding role assigned to the trial court. Appellate courts are simply not as well-equipped to make factual determinations, and allowing them to do so undercuts important functions of the jury system.

\section{B. Appellate Review Under the Different Harmless Error Tests}

An appellate court deciding a harmless error case must make a determination that is largely factual in nature. Whether one considers it to be a question of pure fact or a mixed question of law and fact, ${ }^{128}$ a determination involving fact is unavoidable given the nature of the doctrine. However, an appellate court may engage in varying degrees of factfinding, depending upon the test of harm it applies.

As will be shown below, factual inquiry under the contribution-to-conviction test is considerably more circumscribed and focused than inquiry under the competing tests. Under the Chapman contribution-to-conviction test, factual inquiry is confined to assessing whether the jury's guilty verdict could not reasonably have been influenced by the error. Under the Harrington overwhelming-evidence test, the factual inquiry is considerably less confined, as the court assesses guilt in general, rather than trying to conclude what effect an error may have had on a jury. Under the Van Arsdall balancing approach, a court considers both the effect of the error and the general evidence of guilt, and then balances the two. These three

(addressing the scope of prosecutorial discretion and the entryways it paves for racial and ethnic prejudice).

126. See, e.g., Alan Abrahamson, Ethics Probe of Judge Referred to State Bar, L.A. Temes, June 30, 1993, at A3 (reporting allegation that judge may have been biased towards certain lawyers that gave him gifts); Mark Silk, Panel on Bias Doesn't Let Witmesses Name Names: Lawyer Tries to Identify Prejudiced Judges, ATLANTA J. \& CoNsT., Oct. 2, 1993, at B5 (discussing allegation by black lawyer that certain judges in her circuit are prejudiced).

127. Cf. United States v. Innamorati, 996 F.2d 456, 475 (1st Cir. 1993) (The harmless error test "comes close to a trespass upon the jury's function.").

128. The question of harmless error is most likely a mixed question, because it requires the application of a legal standard to the facts of a case. See, e.g., Larson v. Tansy, 911 F.2d 392, 394 (10th Cir. 1990) ("The harmless error issue is most likely a mixed question of law and fact . ..."). The prototypical mixed question is that of negligenee. See Christie, supra note 100, at 14 ("Perhaps the most frequently given example of a mixed question of law and fact is the question of whether a person is 'negligent.' "). 
approaches differ in the standards of proof used and in the processes of discrepancies in application.

\section{The Different Standards of Proof Required to Label an Error Harmless}

What is the difference between requiring overwhelming proof of guilt versus requiring proof beyond a reasonable doubt that an error did not contribute to the verdict? In other words, what degree of certainty must a court possess to affirm a conviction under each of the separate tests? Given the inherent ambiguity of such mental calculations, definitive conclusions along this line are impossible. A general conclusion, however, is possible. While the decisional requirements of the Chapman test are apparent and strict, the constraints imposed by both the Harrington test and the Van Arsdall test are relatively loose.

The Chapman test requires an examination of whether the error in question possibly affected the decision of "at least one member of the jury." 129 The government thus must carry a very heavy burden if it hopes to win affirmance under this test. ${ }^{130}$ The government must show that the error was so unimportant that it could not reasonably have impacted the verdict. $^{131}$ When, for example, evidence is wrongly admitted, the evidence must have been so nugatory or farfetched that no juror could possibly have relied on it. Or, as Professor Saltzburg says: "because of the enormous burden of proof placed on the prosecutor in criminal cases, a sniall showing of prejudice should suffice to convince an appellate court that an error during the course of the trial was reversible."132 If the error may have

129. Kordenbrock v. Scroggy, 919 F.2d 1091, 1097 (6th Cir. 1990) (en banc) ("The Court must entertain with an open mind the possibility that at least one member of the jury took the language of the [erroneously admitted] confession seriously and relied on the harshness of its description to tip the balance in favor of the death penalty."), cert. denied, 499 U.S. 970 (1991); accord Satterwhite v. Texas, 486 U.S. 249, 258 (1988) (question is whether error "might have affected" outcome); United States v. Szymaniak, 934 F.2d 434, 440 (2d Cir. 1991) ("An error is not harmless if there is a reasonable possibility that the improperly admitted evidence contributed to the conviction." ") (citation omitted); United States v. Khoury, 901 F.2d 948, 961 (11th Cir. 1990) ("Unless we conclude that there is no 'reasonable possibility that the evidence complained of might have contributed to the conviction[,]' we cannot hold a constitutional violation harmless.") (alteration in original). 22.

130. The government bears the burden of persuasion regardless of the test applied. See supra note

131. The Yates Court explained this burden, indicating its strict nature:

To say that an error did not "contribute" to the ensuing verdict is not, of course, to say that the jury was totally unaware of that feature of the trial later held to have been erroneous. ....

To say that an error did not contribute to the verdict is, rather, to find that error unimportant in relation to everything else the jury considered on the issue in question, as revealed in the record.

Yates v. Evatt, 500 U.S. 391, 403 (1991), overruled on other grounds by Estelle v. MeGuire, 502 U.S. 62 (1991) (ovemuling Yates holding on jury instructions).

132. Saltzburg, supra note 5 , at 1014. 
impacted or contributed to the verdict at all, reversal should follow under Chapman.

It is difficult to state the decisional requirements of the Harrington test, which asks whether overwhelming, untainted evidence of guilt exists. "Overwhelming evidence" is a vague standard that has been interpreted by courts and commentators in a variety of ways, including: (a) so much untainted evidence "that the jury would necessarily find the defendant guilty" on that evidence alone; ${ }^{133}$ (b) so inuch untainted evidence that "it is clear beyond a reasonable doubt that if the jury had never [been exposed to the error] its verdict would have been the same;"134 (c) so much untainted evidence that the average jury "would not have found the State's case sigmificantly less persuasive" absent the error:;135 (d) so much untainted evidence that the court "can say, with fair assurance . . . the judgment was not substantially swayed by the error;"136 and (e) so inuch untainted evidence that "there is no substantial possibility that the result would have been any different." 137 This confusion is exacerbated when a court merely asserts the standard without explaining its demands. ${ }^{138}$

These various standards range from very lenient to relatively strict. If overwhelming evidence means that conviction in an error-free trial was more likely than not or is simply possible given the independent evidence, then the standard of proof under this rule clearly differs from that under the contribution-to-conviction rule, and is much more lenient. Such a rule asks whether the error played such a significant role in the trial that it substantially affected the jury's decision, rather than possibly or probably affected the decision. In contrast, if overwhelming evidence means that conviction is "virtually certain" or guilt was established beyond a reasonable doubt given the independent evidence, then this rule becomes stricter. Under this interpretation, the probative value of the untainted evidence presumably must be very high to satisfy the rule's requirements.

In sum, the overwhelming-evidence standard may be read in strict or lenient terms. Contrary to the contribution-to-conviction standard, there is no general agreement on its meaming. ${ }^{139}$

133. Field, supra note 70 , at 18 n.9.

134. United States v. Clemons, 843 F.2d 741, 753 (3d Cir. 1988) (citation omitted), cert. denied, 488 U.S. 835 (1988).

135. Schneble v. Florida, 405 U.S. 427,432 (1972).

136. Hughes v. Borg, 898 F.2d 695, 701 (9th Cir. 1990) (internal quotation omitted).

137. James v. Commonwealth, 679 S.W.2d 238, 240 (Ky. 1984), cert. denied, 470 U.S. 1086 (1985).

138. See Umited States v. Lane, 474 U.S. 438, 477 (1986) (Stevens, J, concurring and dissenting in part) ("[T]he majority utterly fails to explain its statement about 'overwhelming evidence." "); see also United States v. Hasting, 461 U.S. 499,512 (1983) (bare assertion that evidence is "overwhelming"); United States v. Pena, 897 F.2d 1075, 1083 (11th Cir. 1990) (saine); United States v. Motley, 940 F.2d 1079, 1084 (7th Cir. 1991) (same).

139. Whatever the overwhelming evidence standard is, however, it surely cannot (or should not) be the familiar sufficiency standard used to evaluate insufficient-evidence challenges. See, e.g., United States v. Khoury, 901 F.2d 948, 960 (11th Cir. 1990) ("In a sufficiency analysis we review the evidence 
It is perhaps more difficult to describe the Van Arsdall test, under which the reviewing court balances the untainted evidence against the error's effect. The Van Arsdall Court indicated only that an error must be harmless beyond a reasonable doubt. It failed to specify how slight the inpact of the error or how great the untainted evidence inust be before an error is deeined harmless. ${ }^{140}$ The lesser the impact found before declaring an error harmful, the closer this test comes to that of Chapman. ${ }^{141}$ The greater the independent evidence required to declare an error harmless, the closer this test comes to a strict version of the Harrington test. Because the Van Arsdall approach may incorporate the overwhelming-evidence test, a large grey area exists as to what proof suffices to declare an error harmless under Van Arsdall.

Thus, the prinary problem with the Van Arsdall "scoreboard"142 approach to harmless error is that no single accepted standard of proof exists. In this regard, the Van Arsdall approach resembles the Harrington approach. Whereas the Chapman test requires harmless error review to be uniformly strict, requiring reversal if the error had any possible causal impact on the verdict, ${ }^{143}$ the remaining tests permit movement between a fairly lenient review of the record and a very strict review. In the absence of specific dictates to the contrary, courts can theoretically give whatever content they desire to these rules, so long as they satisfy the ambiguous constraint that the error be deemed harmless beyond a reasonable doubt. ${ }^{144}$

to determine whether the government has satisfied the minimum required in order for a reasonable juror to find guilt beyond a reasonable doubt.").

As one conimentator has asserted, "[s]ufficient evidence to convict, once the tainted evidence is removed, is inadequate to support a finding of harmless error, because a jury may acquit though the evidence is sufficient to refer the case to it." Field, supra note 70, at $18 \mathrm{n} .9$; see also Lane, 474 U.S. at 476 (Stevens, J., concurring and dissenting in part) ("[H]armless-error inquiry is entirely distinct from a sufficiency-of-the-evidence inquiry."); Khoury, 901 F.2d at 960 ("standard cuts more sharply against the government" in harmless error analysis than in sufficiency analysis); Holland v. Attorney Gen. of New Jersey, 777 F.2d 150, 158 (3d Cir. 1985) ("A harmless error inquiry into whether evidence of guilt was overwhelming cannot be collapsed into whether it was sufficient.").

140. See Delaware v. Van Arsdall, 475 U.S. 673, 684 (1986) (delineating the test and remanding the case for application of the test, thus failing to provide a factual setting from which to discern how the Court would apply the test).

141. For an example of exacting comparison of erroneous evidence to other, untainted evidence, see Collazo v. Estelle, 940 F.2d 411, 424-26 (9th Cir. 1991), cert. denied, 112 S. Ct. 870 (1992). There, the court concluded that admission of erroneous evidence was not harmless because the erroneous evidence "was clearly not 'unimportant in relation to everything else the jury considered on the issue." " Id. at 426 (quoting Yates v. Evatt, 500 U.S. 391, 403 (1991)).

142. Commonwealth v. Mahdi, 448 N.E.2d 704, 714-15 (Mass. 1983) (describing the weighing of various factors in harmless error analysis as a "scoreboard method to distinguish harmless from harmful error').

143. See Traynor, supra note 35, at 35-36 (describing the great stringency of the Chapman test).

144. It is also clear, however, that a sufficiency standard is not adequate. See supra note 139; sec also Yates, 500 U.S. at 407 (rejecting state court's harmless error analysis because it may have been only a sufficiency standard). 


\section{The Process of Applying the Tests}

The various harmless error tests also differ in the process by which they are applied. Different foci of attention under the tests lead to different processes of appellate review. The contribution-to-conviction test directs attention to one specific aspect of the trial record: the nature of the error and the context in which it occurred. The overwhelming-evidence test directs attention away from the error to the weight of the supposedly unaffected evidence. The hybrid test directs attention to both aspects of the record. With these changes in perspective comes a change in the required amount of judicial inquiry into the record. The Chapman test generally requires less investigation than the Harrington test, which in turn generally requires less investigation than the Van Arsdall test.

These general statements are easily comphicated. Often, to make sense of an error, a court employing the Chapman test must investigate the whole record, although the most a court should ever consider is the evidence that the jury actually considered. ${ }^{145}$ For instance, to assess the impact of an improper jury instruction, a court may have to examine all the evidence to determine whether the imstruction may have caused certain evidence to be improperly ignored or exaggerated.

On the other hand, certain errors may be of a type where isolated analysis suffices. For example, the probable impact on a jury of a confession introduced at trial but later deemed involuntary may become apparent after a reading of the confession itself. ${ }^{146}$ However, even when Chapman requires a more searching inquiry, this inquiry should make sense of the error and not weigh the surrounding record. ${ }^{147}$ That is, even if the whole record is investigated, the inquiry should not devolve into looking for overwhelming evidence of guilt or coinparing the error's impact to the impact of untainted evidence.

Conversely, inquiry under the Van Arsdall test may be more limited than one might expect. In Numan v. State, ${ }^{148}$ the Arkansas Supreine Court, employing a test very similar to the Van Arsdall test, ${ }^{149}$ discussed how this might be so:

145. See Yates, 500 U.S. at 404 ("[A court reviewing error under Chapman] must ask what evidence the jury actually considered in reaching its verdict.").

146. See, e.g., United States ex rel. Hanrahan v. Thieret, 748 F. Supp. 603, 611 (N.D. Ill. 1990) ("Even if every fact [the defendant] related had been fully corroborated by other evidence ... that could not have had the same kind of inpact on the jury as would [the defendant's] own admission."), rev'd, 933 F.2d 1328 (7th Cir. 1991).

147. See Field, supra note 70 , at 18 (arguing that, even when looking at the entire record to place the error in context, the purpose of review under Chapman "is solely to trace the impaet of the erroncously admitted evidence").

148. 722 S.W.2d 276 (Ark. 1987).

149. The Arkansas Supreme Court later characterized the Numan test in terms identical to those used to describe the hybrid test in this Comment: "In Numan we weighed the gravity of the error against the evidence of guilt." Jarreau v. State, 722 S.W.2d 565, 567 (Ark. 1987); see also supra text accompanying note 25 . 
[When] constitutional error [is] slight ... we consider the weight of the evidence in order to determine whether the error was harmless. We weigh the evidence in this second stage because even slight error cannot be said to be harmless in a case in which the question of guilt or innocence is a close one, but it can be in a case where the evidence of guilt is overwhelming. ${ }^{150}$

Thus, when a court taking this two-step approach ends its inquiry because the error is not "shight," then review of the record will indeed be as limited as that under the Chapman approach.

Contrary to the typically confined review under the Chapman test, inquiry under the Harrington test is largely unfettered. The reviewing court makes its own determination of guilt beyond a reasonable doubt. In doing so, it does not attempt to confine its review to the evidence actually considered by the jury. If the court finds one bit of evidence that is, in its opinion, damning, then mquiry can end. If the court finds one bit of exculpatory evidence, inquiry may also end.

The fact that each of these tests may require review of the entire record does not mean that the modes of review are identical. The primary distinction remains one of focus: under Chapman, the meaning and effect of the error alone is the concern; under Van Arsdall, the importance of the error will be weighed against the evidence of guilt; under Harrington, the effect of the error may come into play, but the primary concern is evidence of guilt.

This variation in methods of review indicates how choice of test alone may determine the outcome of the review. ${ }^{151}$ Consider a case in which an incriminating confession is wrongly admitted and where independent overwhelming evidence of guilt exists. The Chapman test would call for reversal, whereas the Harrington test would call for affirmance. On the other hand, consider a case in which erroneously admitted evidence is insignificant and where no other overwhelming evidence exists. The overwhelming-evidence test would now dictate reversal, and the contribution-toconviction test would not. ${ }^{152}$ Under the Van Arsdall test, the outcome would depend on the siguificance of the error when weighed against the independent evidence.

150. Numan, 722 S.W.2d at 279.

151. See Field, supra note 70, at 19 ("TT] different standards can lead to conflicting dispositions of the same case.").

152. See Hunter v. Clark, 906 F.2d 302, 309 (7th Cir. 1990) ("[W] have ... held constitutional errors harmless even in the absence of 'overwhelming' evidence, focusing instead on the 'impact of the objectionable inaterial on the jury's verdict.' ") (quoting Fencl v. Abrahamson, 841 F.2d 760, 769 (7th Cir. 1988)), vacated, No. 89-2594, 1990 U.S. App. LEXIS 16647 (7th Cir. Sept. 17, 1990), on reh'g, 934 F.2d 856 (7th Cir.) (en banc), cert. denied, 112 S. Ct. 388 (1991). 


\section{The Sum of These Differences}

Because the Supreme Court has not definitively selected one harmless error test, lower courts have great discretion in their choice of test. In general, greater discretion increases the likelihood of abuse. ${ }^{153}$ However, a rule prohibiting discretion altogether might eliminate some desirable flexibility. Discretion is thus not always undesirable. Nevertheless, one commentator has concluded that, at least in the context of the criminal justice system,

the greatest and most frequent injustice occurs [where discretion is greatest], where rules and principles provide little or no guidance, where emotions of deciding officers may affect what they do, where political or other favoritism may influence decisions, and where the imperfections of human nature are often reflected in the choices made. ${ }^{154}$

It follows, then, that "injustice" should be rife in harmless error cases, ${ }^{155}$ because the doctrine is replete with discretion. ${ }^{156}$ Most notably, a reviewing court has the power to choose between three broad tests of harm that lead to disparate results when applied. ${ }^{157}$

Additionally, whereas the Chapman test imposes a stringent standard of proof and a focused method of review, the Harrington test gives broad discretion to the reviewing court in its determination of the standard of proof and in its examination of the record. The Van Arsdall test likewise gives reviewing courts greater freedom than the Chapman test in these respects.

This does not mean that the latter test will always be preferred by defendants. The Chapman test may well lead to affinnance of a conviction in a case where the Harrington test would lead to reversal. ${ }^{158}$ Permission of greater discretion does not by itself indicate that the Harrington and Van Arsdall tests are uniformly less favorable to defendants. These tests are

153. For a discussion of the pros and cons of discretion, see Kathleen M. Sullivan, The Supreme Court, 1991 Term-Foreword: The Justices of Rules and Standards, 106 HARv. L. REv. 22 (1992); see also Antonin Scalia, The Rule of Law as a Law of Rules, 56 U. CHI. L. REv. 1175 (1989) (favoring limited judicial discretion).

154. Kenneth C. Davis, Discretionary Justice: A Preliminary Inquiry at v (1969). The institution of determinate sentencing guidelines in the federal system reflects the belief that greater discretion leads to greater unfaimess. See U.S. Sentencing Comm'N, Federal Sentencing GudDelines MANUAL 2 (1991) (objeetive of guidelines was to institute a "fair sentencing system" that was honest, proportional, and uniform).

155. Of course, actual injustice inust be assessed on a case-by-case basis. See, e.g., Michael L. Radelet et al., In Spite of Innocence: Erroneous Conviction in Capital Cases (1992) (studies of probable erroneous convictions in death penalty cases); Hugo A. Bedau \& Michael L. Radelet, Miscarriages of Justice in Potentially Capital Cases, 40 Stan. L. Rev. 21 (1987) (same).

156. In specific reference to the harmless error doctrine, Chief Justice Weintraub of the New Jersey Supreme Court said: "The statement of any formula is more likely to summarize the result than to assist in reaching it, for a reviewing judge exereises a delicate discretion which cannot be contained by any set of words." State v. Maeon, 273 A.2d 1, 6 (N.J. 1971) (citation omitted).

157. See supra Section I.B.

158. See supra note 152 and accompanying text. 
capable of producing stringent decision standards and may be applied in ways favorable to the defendant. The practical comparison of cases does suggest, however, that courts utilizing the Harrington test rarely reverse, and courts reverse less often than not under the Van Arsdall test. ${ }^{159}$

Because the Harrington test allows a less stringent and more involved review of the trial record than does the Chapman test, the Harrington test tends to favor the prosecution. Conversely, the Chapman test tends to favor the defendant. To better understand each test, it is helpful to take the perspective of the appellant (the defendant at trial) and respondent (the prosecution at trial) in a harmless error case.

If you were the appellant, which test would you choose? Even if you did not know that courts appear more likely to reverse under Chapman, you would still probably argue for Chapman. The reason is simple: the standard is clear and strict.

Although the respondent bears the burden of persuasion, the appellant can easily construct a possible scenario in which the error had some effect. In a case of erroneously admitted evidence, for example, to demonstrate that the error might have contributed to the conviction, the appellant would likely need to show only that the erroneously admitted evidence was believable. Other, untainted evidence that may be very probative of guilt can be ignored. Essentially, the appellant can now argue from the perspective of a citizen whose constitutional rights have been violated and who seeks only a fair trial, ${ }^{160}$ and can avoid the appearance of a convicted felon who is trying to downplay the evidence of his or her own guilt.

The government, meanwhile, would likely argue for the Harrington test, because it is neither clear nor necessarily strict. Under Harrington, courts can ignore even significant and highly prejudicial error and can concentrate on the facts that resulted in a finding of guilt. Because the meaning of "overwhelming evidence" is unclear, only one or two pieces of incriminating evidence might be sufficient to construct a plausible argument for the overwhelmingness of this evidence. Most importantly, the government can now argue for integrity and truth-seeking in the criminal justice system, ${ }^{161}$ rather than discussing error often directly attributable to its own actions.

To date, the Court has failed to dictate a single, controlling rule of harmless error. Hence, the degree of protection that one's constitutional

159. See id.

160. The appellant will likely quote words to the effect that "a conviction cannot constitutionally be based to any extent on constitutional error." Harrington v. Califomia, 395 U.S. 250, 255 (1969) (Brennan, J., dissenting).

161. Indeed, quotations of the following sort will undoubtedly find their way into the government's brief:

There is danger that the criminal law will be brought into contempt-that discredit will even touch the great immunities assured by the Fourteenth Amendment-if gossamer possibilities of prejudice to a defendant are to nullify a sentence pronounced by a court of competent jurisdiction in obedience to local law, and set the guilty free.

Snyder v. Massachusetts, 291 U.S. 97, 122 (1934), overruled by Malloy v. Hogan, 378 U.S. 1 (1964). 
rights receive may depend greatly on an arbitrary or biased choice of harmless error test. Proponents of a law and order approach may apply the overwhelming-evidence test, with its surrounding ambiguities, to gain greater control over the review process. Opponents of the prosecution may, on the other hand, choose the strict contribution-to-conviction test. The question remaining, then, is how this broad discretion should be eliminated.

\section{III}

\section{The Need for Greater Restraint in Harmless Error REVIEW}

The Supreme Court's endorsement of the overwhelming-evidence form of review allows considerable judicial activism at the appellate level. The overwhelming-evidence test essentially grants appellate courts the power to decide the issue of guilt.

The Court's move from requiring deference to the trial court to allowing appellate activism in harmless error cases most likely stems from the Court's increasing focus on result, instead of process, in criminal trials. ${ }^{162}$ For example, in Delaware v. Van Arsdall, ${ }^{163}$ the Court stated:

The harmless-error doctrine recognizes the principle that the central purpose of a criminal trial is to decide the factual question of the defendant's guilt or innocence, and promotes public respect for the criminal process by focusing on the underlying fairness of the trial rather than on the virtually inevitable presence of iminaterial error. ${ }^{164}$

Thus, "the Court's notion of 'fair trial' is a trial that is desigued to produce a reliable outcoine."165 Factual accuracy has been exalted as the "central purpose"166 of a defendant's constitutional rights at trial. This perspective, however, overlooks the importance of providing not only a "fair"

162. The Court's couception of a fair trial as a trial that leads to the "right" result is also evinced in its ineffective assistance of counsel cases, where a defendant may prevail only if he proves prejudice. Ineffective counsel alone is thus not dispositive, as long as the trial reached the "right" result. See Strickland v. Washington, 466 U.S. 668, 691-96 (1984).

163. 475 U.S. 673 (1986).

164. Id. at 681 (citation omitted). This point was reiterated in Rose v. Clark, 478 U.S. 570 (1986):

The thrust of the many constitutional rules governing the conduct of criminal trials is to ensure that those trials lead to fair and correct judgments. Where a reviewing court can find that the record developed at trial establishes guilt beyond a reasonable doubt, the interest in faimess has been satisfied and the judgment should be affirmed. As we have repeatedly stated, "the Constitution entitles a criminal defendant to a fair trial, not a perfect one."

Id. at 579 (quoting Van Arsdall, 475 U.S. at 681).

165. Campbell, supra note 7 , at 516. "Reliability" generally means the extent to which an experiment or test yields the same result repeatedly (i.e., it connotes dependsbility). See, e.g., Geofrey Keppel \& Sheldon Zedeck, Data Analysis for Research Designs: Analysis of Variance and Multiple Regression/Correlation Approaches 449 (1989) (discussing "reliability"). "Accuracy" is perhaps the better term to describe the court's goal, for accuracy means the extent to which an experiment or test is free from error or mistake (i.e., it connotes correctness).

166. See Van Arsdall, 475 U.S. at 681. 
result, but also a fair process to reach that result. An accurate result depends on a fair trial. Moreover, in some cases the fair result will not be the factually accurate result. A jury may very well acquit a defendant it believes to be guilty under the letter of the law. The Court's emphasis on result is therefore only one way of determining the proper test of harmless error, and it may well be an incomplete approach that leads to an erroneous conclusion.

The defendant's Sixth Amendment right to a jury verdict dictates adoption of the harmless-error test that best limits appellate-level intrusion on the jury's factfinding role. It is worth remembering that if a court finds an error harmful, the remedy is a new trial, not a permanent release. Reversal for harmful error means only that the defendant will have a second chance at a fair result by a fair process.

Additionally, values other than preservation of the jury's role call for greater appellate deference to trial court decisions in harmless error cases. As Justice Stevens noted, "our Constitution, and our criminal justice system, protect other values besides the reliability of the guilt or innocence determination."167 The proper way to approach this question of values is not simply to ask which value should predominate, but rather first to ask whether values must be traded off, and if so, then to ask how these tradeoffs should be made.

On the one hand, the overwhelming-evidence test, by allowing a conviction to stand where a trial has been significantly affected by constitutional error, ${ }^{168}$ is simply too lenient. The overwhelming-evidence test ignores the argument that, even if conviction appears inevitable, there is a point at which an error becomes too great to condone as a matter of constitutional integrity and prosecutorial deterrence.

One goal of the harmless error doctrine is the preservation of public respect for the judicial system by not reversing for nonprejudicial errors. ${ }^{169}$ Yet this public respect may also be undermined when significant errors go uncorrected, and when constitutional rights thus go unprotected. Moreover, if committing an error has no adverse effect on the state, the deterrence of official misbehavior becomes difficult. ${ }^{170}$ Indeed, the failure to overturn a conviction that is arguably the fruit of an error may reinforce governmental error and abuse.

167. Rose, 478 U.S. at 588 (Stevens, J., concurring).

168. See United States v. Innamorati, 996 F.2d 456, 476 (1st Cir. 1993) (reversal not required for even weighty errors if overwhelming evidence of guilt is apparent to the appellate court); Campbell, supra note 7, at 510 ("[T] $]$ he rationale of the overwhelming evidence test is that, regardless of how prejudicial the constitutional error might be, a conviction should not be reversed if the case against the defendant was so strong that a conviction was mevitable.").

169. See Van Arsdall, 475 U.S. at 681 (discussing rationale for harmless crror doctrine).

170. See Vilija Bilaisis, Comment, Harmless Error: Abettor of Courtroom Misconduct, $74 \mathrm{~J}$. Crim. L. \& CRIMINOLOGY 457, 470 (1983) ("The affirmance of convictions obtained in violation of . . rulcs [regulating the conduct of prosecutors and judges] discourages adherence to the rules."). 
The opposite concern, that too strict a test would lead to reversal for trivial error, is also valid, at least theoretically. However, even the strictest harmless error test would not require reversal for insignificant errors. One need not fear that courts will become "impregnable citadels of technicality," error was of some import before reversing. ${ }^{172}$ Careful and faithful application of the Chapman test thus eliminates concerns about hypertechnicality.

Perhaps even more troubling than the Court's focus on reliability to the exclusion of other values is the Court's belief that the overwhelming-evidence test preserves "correct" verdicts. In fact, this test does not ensure reliability, because it establishes as factfinders persons in a poor position to examine facts. ${ }^{173}$ If truth is what the Court really seeks through its harmless error doctrine, it should adhere to the Chapman test, which favors factual determinations by the trial court over those by the appellate court. The Chapman approach best preserves the well-justified judicial division of labor.

When the different harmless-error tests are examined closely, it is apparent that no true value trade-off exists. The primary value thought to be served by the Harrington approach-reliability-is in fact better served by the Chapman approach. And the Chapman approach, unlike the Harrington approach, serves this value without simultaneously denigrating other values.

In a recent harmless error case, the Court echoed many of the concerns voiced here about appellate activisn. In Sullivan v. Louisiana, ${ }^{174}$ the Court considered whether an unconstitutional instruction on reasonable doubt should be subjected to harmless error review. The Court's conclusion to the contrary was founded on its belief that appellate review in this case would call for too nuch speculation by the appellate court. ${ }^{175}$ length:

The Court's owu explanation in Sullivan is worth quoting at some

In Chapman v. California, we rejected the view that all federal constitutional errors in the course of a criminal trial require reversal. . . . The Chapman standard recognizes that "certain constitutional errors, no less than other errors, may have been 'harmless' in terms of their effect on the factfinding process at trial." Although most constitutional errors have been held amenable to harmlesserror analysis, sonte will always invalidate the conviction. The

171. Marcus A. Kavanagh, Improvement of Administration of Criminal Justice by Exercise of Judicial Power, 11 A.B.A. J. 217, 222 (1925), quoted in TrAYNor, supra note 35, at 14.

172. See supra text accompanying note 3.

173. See supra Section II.A.

174. 113 S. Ct. 2078 (1993).

175. See id. at 2081-82. 
question in the present case is to which category the present error belongs.

Chapman itself suggests the answer. Consistent with the jurytrial guarantee, the question it instructs the reviewing court to consider is not what effect the constitutional error might generally be expected to have upon a reasoniable jury, but rather what effect it had upon the guilty verdict in the case at hand. Harmless-error review looks, we have said, to the basis on which "the jury actually rested its verdict." The inquiry, in other words, is not whether, in a trial that occurred without the error, a guilty verdict would surely have been rendered, but whether the guilty verdict actually rendered in this trial was surely unattributable to the error. That inust be so, because to hypothesize a guilty verdict that was never in fact rendered-no inatter how inescapable the findings to support that verdict might be-would violate the jury-trial guarantee.

Once the proper role of an appellate court engaged in the Chapman inquiry is understood, the illogic of harmless'error review in the present case becomes evident. ${ }^{176}$

This analysis in Sullivan, though not directly on point, ${ }^{177}$ has obvious, negative implications for the viability of the overwhelming-evidence test, which always requires a hypothesized guilty verdict. If the "proper role" for an appellate court engaged in harmless error review is not to predict what result a hypothetical, error-free trial would have produced, but rather to assess the probable effect an error had on the actual verdict rendered, then the Chapman test inust be the test of choice, for only it directs a court to this inquiry. The Chapman test preserves the proper role of the appellate court, whereas the Harrington overwhelming-evidence test obscures it.

Whether the Court will carry its statements in Sullivan to their logical conclusion remains to be seen. If the proper role of the appellate courts is to be restored, and the proper degree of deference accorded to trial courts' findings of fact, then the overwhelming-evidence test must be eliminated.

\section{CONCLUSION}

In harmless error cases today, winning the legal battle over which test controls gives one a great advantage in the factual battle over whether the error was harmless. Under present conditions, a defendant's chances of being granted a new trial may depend more on which harmless-error test is

176. Id. (citations omitted).

177. In Sullivan, the Court declined to engage in harmless error review altogether, because there had been no actual jury finding of guilt "within the meaning of the Sixth Amendment." Id. at 2082. The question in Sullivan was whether harmless review should be conducted at all with respect to a constitutionally deficient reasonable doubt jury instruction. In answering this question in the negative, the Court advanced a theory of appellate restraint that accords with the analysis of proper harmless error review presented in this Comment. See Nichols, supra note 13, at 1024 (agreeing that Sullivan indicates a turn away from appellate courts acting as "primary fact-finder[s]" in harmless error cases). 
chosen than on the facts of her case. Indeed, it is quite possible that defendants with identical fact situations might receive opposite results if their cases are reviewed under different tests of harm. In effect, a court's choice between the Chapman, Harrington, and Van Arsdall tests may determine freedom or imprisonment, life or death.

The Court's vacillation between the various standards cannot be attributed to its failure to notice the disparity. Justice Stevens, for example, has argued that "[a] federal appellate court should not find harmless. error merely because it believes that the other evidence is "overwhelming.' "178 He further explained:

"[I]t is not the appellate court's function to determine guilt or innocence. . . . Nor is it to speculate upon probable reconviction and decide according to how the speculation comes out. ... [T] tion is, not were [the jury] [sic] right in their judgment, regardless of the error or its effect upon the verdict. It is rather what effect the error had or reasonably may be taken to have had upon the jury's decision. The crucial thing is the impact of the thing done wrong on the minds of other men, not on one's own, in the total setting."179

If the Court refuses to address the question of the proper harmless error test because it believes the existing tests do not differ significantly in form or function, this Comment casts serious doubt on that belief. ${ }^{180}$ As things now stand, appellate courts remain free to apply varying standards of proof and to engage in substantial, unguided review of the record to reach their own findings of guilt.

The Court has "repeatedly stated, the Constitution entitles a criminal defendant to a fair trial, not a perfect one."181 Given the current state of harmless error jurisprudence, it unust be added that the Constitution entitles a criminal defendant to a fair "trial by jury," not a "trial by appellate court." Exclusive reliance on the Chapman contribution-to-conviction test of harmless error would restore the proper function of the reviewing court in criminal cases: determining whether a conviction was fair rather than correct.

178. United States v. Hasting, 461 U.S. 499, 516 (1983) (Stevens, J., concurring).

179. Id. (alterations in original) (quoting Kotteakos v. United States, 328 U.S. 750, 763-64 (1946)). Consider also Justice Brennan's dissent in Harrington:

Chapman ... meant no conpromise with the proposition that a conviction cannot constitutionally be based to any extent on constitutional error. The Court today by shifting the inquiry from whether the constitutional error contributed to the conviction to whether the untainted evidence provided "overwhelming" support for the conviction puts aside the firm resolve of Chapman and makes that conpromise.

Harrington v. California, 395 U.S. 250, 255 (1969) (Brennan, J., dissenting).

180. An alternative explanation of the Court's reluctance to act is the possibility that the Court believes the existence of the various tests allows reviewing courts to invoke the test that is more efficient or useful in each case. One commentator has argued also that the Court's alternation between the standards represents an effort to tailor remedies to fit the degree of injury suffered. See Skoglind, supra note 70 , at $967-77$.

181. Rose v. Clark, 478 U.S. 570, 579 (1986) (internal quotation omitted). 
